NBER WORKING PAPER SERIES

FOREIGN CAPITAL AND ECONOMIC GROWTH IN THE FIRST ERA OF GLOBALIZATION

\author{
Michael D. Bordo \\ Christopher M. Meissner \\ Working Paper 13577 \\ http://www.nber.org/papers/w13577 \\ NATIONAL BUREAU OF ECONOMIC RESEARCH \\ 1050 Massachusetts Avenue \\ Cambridge, MA 02138 \\ November 2007
}

Comments from Olivier Jeanne, Paolo Mauro, Brian Pinto, Moritz Schularick and conference participants at the World Bank, Strasbourg Cliometrics, the World Economy and Global Finance Conference at Warwick and the Conference on Globalization and Democracy at Princeton University were very helpful. Seminar audiences at Carlos III, Manchester University, Nova University Lisbon, Paris School of Economics, and Trinity College Dublin also provided generous feedback on an earlier version. Antonio David and Wagner Dada provided excellent research assistance for early data collection. We thank Michael Clemens, David Leblang, Moritz Schularick, Alan Taylor, and Jeff Williamson for help with or use of their data. The financial assistance from the UK's ESRC helped build some of the data set that underlies this paper and supported this research. We acknowledge this with pleasure. Errors remain our responsibility. The views expressed herein are those of the author(s) and do not necessarily reflect the views of the National Bureau of Economic Research.

(C) 2007 by Michael D. Bordo and Christopher M. Meissner. All rights reserved. Short sections of text, not to exceed two paragraphs, may be quoted without explicit permission provided that full credit, including $(\subset)$ notice, is given to the source. 
Foreign Capital and Economic Growth in the First Era of Globalization

Michael D. Bordo and Christopher M. Meissner

NBER Working Paper No. 13577

November 2007, Revised May 2010

JEL No. E22,F21,F32,F43,N1,N20

\begin{abstract}
$\underline{\text { ABSTRACT }}$
We explore the association between income and international capital flows between 1880 and 1913. Capital inflows are associated with higher incomes per capita in the long-run, but capital flows also brought income volatility via financial crises. Crises also decreased growth rates of income per capita significantly below trend for at least two years leading to important short term output losses. Countries just barely made up for these losses over time, so that there is no conditional long-run income loss or gain for countries that experienced crises. This is in contrast to the recent wave of globalization when capital importing countries that experienced a crisis seemed to grow relatively faster over fixed periods of time. We discuss some possibilities that can explain this finding.
\end{abstract}

Michael D. Bordo

Department of Economics

Rutgers University

New Jersey Hall

75 Hamilton Street

New Brunswick, NJ 08901

and NBER

bordo@econ.rutgers.edu

Christopher M. Meissner

Department of Economics

University of California, Davis

One Shields Avenue

Davis, CA 95616

and NBER

cmmeissner@ucdavis.edu 


\title{
Foreign Capital and Economic Growth in the First Era of Globalization
}

\author{
May 20, 2010 \\ Michael D. Bordo \\ (Rutgers University and NBER) \\ Christopher M. Meissner \\ (University of California, Davis and NBER)
}

\begin{abstract}
We explore the association between income and international capital flows between 1880 and 1913. Capital inflows are associated with higher incomes per capita in the long-run, but capital flows also brought income volatility via financial crises. Crises also decreased growth rates of income per capita significantly below trend for at least two years leading to important short term output losses. Countries just barely made up for these losses over time, so that there is no conditional long-run income loss or gain for countries that experienced crises. This is in contrast to the recent wave of globalization when capital importing countries that experienced a crisis seemed to grow relatively faster over fixed periods of time. We discuss some possibilities that can explain this finding.
\end{abstract}

\section{Introduction}

The period from 1880 to 1913 witnessed rising international integration in both goods and financial markets. Many countries joined the industrial bandwagon in this period and others made an effort at jumpstarting the process. What role did foreign capital play in this process? A traditional view holds that a lower cost of capital and greater inflows should have contributed to higher long-run incomes and stronger growth in the late nineteenth century (Fishlow, 1986, Foreman-Peck, 1994, and Collins and Williamson, 2001).

Indeed, many countries experienced a process of industrialization or the transformation to export-orientation and sustained growth of output per capita. At the same time, European capital flowed in large quantities across borders. The areas of recent 
European settlement such as Australia, Canada, the United States, and even parts of Argentina and Brazil enjoyed high wages and incomes witnessing long periods of strong economic growth. Inward investment to these areas, coming largely from Great Britain, mushroomed prior to 1913. In theory these inflows should have boosted the marginal product of labor (and other inputs) and raised incomes in the medium term via accumulation. The conventional view is that foreign capital funded infrastructure such as railroads, harbors, and municipal public works raising productivity.

But the largest recipients of British capital also possessed valuable natural resource endowments and burgeoning populations due to immigration. Indeed, Clemens and Williamson (2004) illustrate that the correlates of strong 'catch-up’ growth and highsteady state income levels such as human capital, a low dependency ratio and an abundant natural resource endowment were the primary determinants of these capital inflows. The question remains whether there is a relation between changes in aggregate income and capital inflows holding other factors constant in this period.

Schularick and Steger (forthcoming) is the only other paper we are aware of that studied this question historically at the aggregate level in a cross-country comparative framework. ${ }^{1}$ They find a positive marginal impact of capital inflows and growth during five year periods between 1880 and 1913 due to a strong correlation between capital inflows and investment.

We continue further in this vein exploring three new facets of the problem. First we investigate the relation between changes in income per capita and foreign capital over short and long horizons. Different growth models have different implications for the time period over which capital flows should matter. Second, we look for evidence that the sector to which foreign capital was directed mattered for the relationship between inflows and incomes. Investment in the many large infrastructure projects of the past may have affected growth differently than inflows of foreign portfolio capital for 'government' purposes.

\footnotetext{
${ }^{1}$ Standard theory suggests opening up to global capital markets can make crucial investment funds available at a lower world cost of capital, but Prasad, Rajan and Subramanian (2007) find little evidence of a positive direct impact of foreign capital on the average growth rate of emerging markets over the last 30 years. Henry argues that recent capital market liberalizations are likely to have had positive but temporary impacts on growth as a neoclassical model of economic growth would predict (Henry, 2007). An extensive list of other similar studies is available in Prasad et. al.
} 
Third, we link capital inflows to the recurrent financial crises of the late nineteenth century. In today's reincarnation of globalization, financial crises have been blamed on premature capital account liberalization in emerging markets but even the overall impact of these ostensibly vicious shocks are still debated. Rancière, Tornell and Westermann (2008) argue that crises cause significant income losses in capital importing countries. However, they also suggest capital inflows deliver rapid growth in non-crisis periods which is likely to offset the negative effects of crises. Countries with high capital inflows grow faster on average than countries with low capital inflows. Other evidence suggests, to the contrary, that decoupling from the global capital market with capital controls in the post-World War II period has protected countries from financial crises in and raised growth (Eichengreen and Leblang, 2003). Which, if any, of these dynamics obtained further back in the past? We investigate by looking at the long and short run association between capital inflows and income losses via their tendency to raise the probability of a banking, currency or debt crisis.

Our results differ significantly from Rancière et. al (2008). In the nineteenth century, many countries with high inflows were indeed more crisis prone like today, but unlike in the Rancière et. al sample for 1961-2000, crisis prone countries in the first wave of globalization did not raise incomes fast enough to significantly make up for the income shocks associated with crises. In other words capital receiving countries exposed to crises in the nineteenth century did not grow faster than non-crisis capital receiving countries. This is not obviously related to differences in the possibility of default and systemic bailouts (key assumptions in the Rancière et. al. framework) though it could be consistent with their model if crises happened frequently enough.

However, consistent with Schularick and Steger, we do find that capital flows yielded a positive 'level effect' on incomes or were associated with above average growth rates of income in the medium run. Still crises, also seem to be associated with substantial negative shocks to income that drag these gains down. Alternatively, the growth rate in non-crisis periods does not seem to have been sufficiently high to offset the lost income associated with crises.

Despite this finding, certain countries avoided crises and took advantage of capital inflows to raise growth. Avoiding crises depended upon a number of financial and policy 
fundamentals that not all countries shared equally. Canada grew rich on the back of capital inflows and avoided severe crises while Argentina also took large inflows but suffered several important crises. We speculate in our conclusions about how the increased volatility mattered, why our results differ from earlier findings for the period, and why they are different from those for the recent period of globalization.

Looking to the past can be useful for guidance on how capital inflows matter for economic growth. Researchers of today's "globalization" have not come to a clear consensus on the growth impact of foreign capital flows. Their time period of observation has been relatively short, the number of less developed countries willing to completely liberalize has been small and, arguably, the rules of the game have changed considerably since central banks, fiscal authorities and multilateral institutions often intervene in market outcomes. History provides insight into a world without these constraints.

\section{International Capital Markets and Economic Growth, 1880 - 1913}

International capital flows were an important feature of late nineteenth century globalization. Although many studies have highlighted their relationship to local investment, empire building, and economic cycles, little recent work has been done using the techniques of the modern empirical growth literature. ${ }^{2}$ To understand the role of foreign capital itself, there are a number of challenges including measuring the amount of integration, discerning whether capital simply chased other factors and flowed to areas with higher potential for growth (i.e., endogeneity) and how much capital's impact depended on local conditions such as property rights, credible commitments, local financial development and other institutional factors. Finally there are more transparent theoretical and empirical identification issues. We discuss each in turn.

\subsection{Measuring Integration prior to World War I}

\footnotetext{
${ }^{2}$ Schularick and Steger (forthcoming) is an exception.
} 
The period between 1880 and 1913 was one of rapidly rising integration in international capital markets. ${ }^{3}$ Capital moved across borders free of government controls. Cross border, market-based financing for public and private projects in both the developed and the less-developed regions played an important role in shaping the amount of capital available in local economies. We focus here on how much capital flowed across borders relative to local GDP.

Several different data sets are available for scholars to assess net capital inflows by country in the nineteenth century. Indirect measures of capital inflows are available by using the simple balance of payments accounting identity. Such data are only available for a limited set of countries and they often do not contain reliable information on data from income earned on foreign investments, transfers and 'invisible' services.

An alternative source of information on capital inflows is information on capital issues on the London financial market from the financial press and other primary sources. Leland Jenks and Matthew Simon used such sources, and their data are re-compiled in the 'capital calls' data published by Stone (1999). These data come largely from information on new equity and bond issues in London which were listed in the Investors' Monthly Manual though many other leading financial newspapers, parliamentary reports and prospectuses were also used as documented in Stone (1999) Appendix A. In the original data, the use of other reports and a detailed analysis of each security allowed Simon to ascertain the actual amount of money paid by investors to the issuer. That said, the actual amount of new 'real' or physical investment abroad is not obviously equal to the value of the 'capital calls' listed in the financial press and other sources. The actual amount of new physical investment in the receiving economy which resulted from such issues would depend on the use to which such funds were put and where they were used. This is why the literature on British capital flows before 1913 distinguishes between financial capital and real capital transfers. Also the ultimate purchaser of the securities listed would affect the amount of net capital flows to the issuing country. In this regard, it is not clear that 100 percent of all purchasers were British residents, but, assuming assets issued abroad simultaneously were a small portion of overall capital issued, this is a

\footnotetext{
${ }^{3}$ Cottrell (1975), Edelstein (1982) and Davis and Huttenback (1986) provide an overview of British capital exports during the nineteenth century.
} 
reasonable assumption. Stone's data are best at highlighting portfolio capital flows, and they do not adequately capture short-term movements of capital nor long-term direct investment. $^{4}$

The literature on measuring capital flows is voluminous and scholars such as Davis and Huttenback (1986) have produced alternative series, but still, their series correlate with those from Stone (1999) with a correlation coefficient of 0.92 (Davis and Huttenback, p. 37). Stone's data on capital calls also correlate highly with the current account information available from Jones and Obstfeld (2003). Country-fixed effects regressions of the current account deficit on the ratio of capital calls to GDP yield coefficients of .38 (t-statistic $=$ of 5.26), and raw correlation coefficients are higher.

Figure 1 shows within group average ratios of capital calls to GDP in three types of countries: a low-income but institutionally advanced core, the high-income per capita British offshoots plus the United States, and the poorer regions of the world. ${ }^{5}$ Foreign investment often equalled up to 20 percent of total capital formation in the typical developing country of the time and up to 50 percent in Australia, Canada, Argentina and Brazil (cf. Fishlow, 1986, Williamson, 1964 and Edelstein, 1982).

\subsection{Where Did the Capital Go?}

Up to 40 percent of all British lending between the 1860s and 1913 went to the British Empire, and, of this portion, the bulk ended up in Canada and Australasia. Ferguson and Schularick (2006) argue that lending within the British Empire demanded a lower risk premium than other similar countries outside of the empire. This was natural because property rights were hard to enforce outside the Empire, political ties were stronger, and other institutions, such as the Joint Stock Acts, increased demand for

\footnotetext{
${ }^{4}$ Svedberg (1978) argued that by 1913 direct investment accounted for over 60 percent of all foreign investment.

${ }^{5}$ We define the core countries to include Belgium, Denmark, Norway, Sweden and Switzerland. We place Australia, Canada, New Zealand and the United States into the "offshoots" category. These regions were extensive capital importers and also had a special institutional heritage being members (or once having been members) of the British Empire. The periphery is defined to include Argentina, Austria-Hungary, Brazil, Chile, Egypt, Finland, Greece, India, Italy, Japan, Mexico, Portugal, Russia, Spain, Turkey, Uruguay
} 
colonial assets. Membership in the British Empire allegedly reassured investors that debts would be repaid. And as a matter of fact no British colony ever defaulted in this period.

Clemens and Williamson (2004) take issue with this market failure view and suggest that factor endowments mattered more for the direction of these flows. Canada, the various colonies of Australasia and other new world regions such as the USA which received heavy inflows (both relative to local GDP and in terms of overall British outflows) were richly endowed in natural resources, high in human capital and scarce in labor and physical capital. Such a combination made for the expectation of a relatively safe and high rate of return on investment relative to the domestic opportunities and those available in labor abundant/resource poor Europe. After controlling for these factors, they find that the British empire did not receive greater inflows from Britain than other comparable regions.

\subsection{What Happened to the Capital Inflows?}

Fishlow (1986) characterized countries as revenue borrowers or development borrowers. Development borrowers financed large infrastructure which should have catalyzed economic growth and raised living standards. Revenue borrowers were likely to have severe fiscal deficiencies due to emergency situations or deeper institutional flaws which limited their ability to tax. Borrowing by such countries would not necessarily be expected to raise incomes or growth rates.

Figure 2 shows the shares of capital calls on London from Stone's data for three categories of activity. The government category accounted for about a third of British capital exports. This category included bonds carrying guarantees provided by local governments on interest payments for private and state-owned railways. The countries that devoted the largest share of the inflows to government uses are located on the right of Figure 2 and include Norway, Germany, Denmark, Austria and Australia. Railways (fully private concerns in terms of ownership) captured roughly another third of British capital exports between 1880 and 1913, and Stone (1999) reports that these outflows were concentrated in the US, Canada, Argentina and India which received over 80 percent of these outflows. The US, Argentina and Canada are amongst those devoting the 
highest share of their inflows to railways. Finally, the 'private' category included investments in utilities (sewage, water treatment, electrical generation etc.), financial firms, raw materials extraction, and other industrial and 'miscellaneous' enterprises. Information from sovereign bond prospectuses published in Fenn on the Funds can also be examined to see in more detail the intended uses of foreign capital. ${ }^{6}$ The colonies of Australasia, the future South Africa, and Canada and its provinces borrowed almost exclusively to fund railroads, harbors, sewage systems, and other infrastructure. For these places, the Fenn's summary of investments would often state something to the effect, 'the vast majority of funds have been for internal improvement'.

Other countries like Russia (an issue to strengthen the specie [reserve] fund), Japan (to pay charges on pensions), Egypt (Pasha loan for re-payment of existing debt), and Austria (an issue in 1851 to improve upon the value of the paper florin) borrowed to plug revenue gaps or to fund offensive, defensive and civil wars. ${ }^{7}$ Many of these same countries had considerable amounts of their total debt issues dedicated to unspecified ends.

Of course risky foreign investment was often greeted by the market with low prices at initial public offerings in order to compensate investors. To roughly gauge the

\footnotetext{
${ }^{6}$ It is difficult to sort out whether the listed prospectuses for new issues with unspecified projects were simple consolidations of old productive debt, whether war finance should be classified as productive spending or not (since the vanquished often paid large war indemnities or suffered economic repression, while victors may have seen real benefits), and to know the actual share for each country of sovereign borrowing versus private borrowing. Therefore we have not been able to systematically assess whether countries were revenue or development borrowers for each and every year of the period. Future work could attempt to delineate more clearly each kind of borrower and to correlate this variable with subsequent economic growth. Another problem is that it is not clear whether this source and the productive/revenue dichotomy could adequately characterize countries' prospects. For 1874 we catalogued the issues for the entire set of economically important countries. We found that for countries like the US (federal financing of the Civil War we know), and even Canada (which the very same source reported as being a sound infrastructure borrower), a majority of their issues were listed but with unspecified ends. Compounding the difficulties would be judging between the quality and management of the projects such as railroads that actually seem on paper to be for productive purposes. For example, in Bolivia, one issue was for the construction of a canal to the Atlantic. This project failed to prove technically feasible and the market value of the issue sank.

${ }^{7}$ In 1876 Egypt defaulted on its sovereign debts leading to foreign administration of taxation and spending. See Mitchener and Weidenmier (forthcoming) for a recent summary of the episode. Information about the use to which Egypt put its borrowing was sketchy at best during the run up to default. Fenn's Compendium does not list a single bond prospectus for Egypt thus leaving the reader unaware of how the funds would have been invested. The Cave Report (quoted in Issawi, 1982) which summarized Egypt's finances after the default claimed "...[Egypt] suffers from the ignorance, dishonesty, waste and extravagance of the East, such as have brought her Suzerin [Pasha] to the verge of ruin...caused by hasty and inconsiderate endeavours to adopt the civilization of the West”. Even after default, British auditors found it difficult to evaluate the ultimate destination of borrowed funds.
} 
penalty on the cost of capital, we totalled the face value of each bond listed in Fenn's 1874 edition that clearly stated in the abstracted prospectus whether the bond was issued for infrastructure or other productive investment. ${ }^{8}$ We then divided this value by the total face value of bonds outstanding. In Figure 3 we plotted a sovereign long-term bond yield on a representative bond minus the British consol yield (i.e., one simple proxy for the country risk premium) against this development/revenue measure. ${ }^{9}$ The spread is calculated for a long-term issue listed in London and payable in gold minus the British consol yield.

The yield spread roughly captures the development vs. revenue borrower distinction. The correlation between the spread and the ratio of bonds issued for productive purposes to total bonds is -0.25 . Figure 3 plots the spread versus the ratio and reveals a negative correlation. The coefficient on the spread in a regression is -0.03 and has a robust t-statistic of $-1.96(\mathrm{p}$-value $=0.06)$. Thus the bond spread can be considered a more continuous measure of development versus revenue financing. Figure 3 reveals that both types of countries were able to issue at least some debt on international markets during this period of open capital flows. However, it is clear from the evidence on capital flows presented in Clemens and Williamson (2004) that the development borrowers received the bulk of these funds.

Moreover, the calculation is not perfect. The Ottoman Empire was a fiscal disaster and had a high spread, but Brazil and the US have equivalent (low) measures of productive spending and low spreads. The latter two had sound finances and solid reputations (on Brazil see Summerhill, forthcoming). It is likely that markets had the belief that repayment was not an issue due to previously established credibility.

In sum, a sort of proto-Washington Consensus of free trade, fixed exchange rates, and fairly liberal economies more or less reigned between 1880 and 1913. Capital markets became strongly integrated and many different types of nations relied on foreign capital to finance new projects aimed at developing the local economy, producing for export and stabilizing finances. Recent research leaves as an open question whether

\footnotetext{
${ }^{8}$ The real cost of capital is only roughly related to the risk premium as we measured it. Other factors include the underwriting fees, price at initial public offering, loan specific contractual factors determining the maturity and so forth.

${ }^{9}$ Sovereign yields come from the annual average of all weekly observations on a representative long-term bond in London as compiled by Kris Mitchener and Marc Weidenmier.
} 
capital inflows mattered for sustaining and stabilizing incomes or other factors mattered more.

\section{$\underline{\text { 3. Economic Growth and Foreign Capital: Some Testable Hypotheses }}$}

\section{$\underline{\text { 3.1 Foreign Capital and Economic Growth in a Neoclassical World and Beyond }}$}

The most general theoretical case for capital market integration is nearly the same as that for free trade. Opening to foreign capital allows for resources to be efficiently allocated. One view in development economics is that poor countries are savings constrained, and so foreign capital inflows ease this constraint making greater investment possible. In addition, risk sharing is allegedly enhanced with globally integrated capital markets. It is also argued that policy is improved since footloose capital harnesses errant policy makers. What are the theoretical predictions for economic growth from basic theory?

The effect on growth of a sustained rise in the level of capital inflows is naturally transitory in a neoclassical growth model (Henry, 2007). ${ }^{10}$ The reason is that opening up simply accelerates a country towards its steady state. Booms and busts in capital inflows would be associated with alternate periods of high and low growth relative to a steadystate trend growth value. And, as is well known, long run growth rates depend only on the rate of technological advance. Furthermore, Gourinchas and Jeanne (2006) argue that the welfare effects of capital market liberalization in a neoclassical model are surprisingly small since countries are usually near their steady states already. For capital inflows to support a larger impact on consumption (and income) and a longer lasting impact on growth, one would have to argue that they accompany an unobserved change in the steady state potential of a country or that they improve the growth rate of total factor productivity. Alternatively in an endogenous growth model of the 'AK' variety, the

\footnotetext{
${ }^{10}$ Bekaert, Harvey and Lundblad (2005) find that growth increases by one percent after a liberalization in the modern period.
} 
growth rate would depend directly on the investment rate. As long as investment is sustained, growth remains high.

In addition there is the possibility that there are lags in the impact of foreign capital on economic growth. This is especially relevant in the nineteenth century. Since foreign capital in this period frequently funded large infrastructure projects like railroads or utilities, it may have taken considerable time until the completion of such projects led to significant improvements in GDP beyond higher investment rates. These could occur via their effect on market access, improved public health or incentives for urbanization. Williamson (1964), Cottrell (1975) and Eichengreen (1995, p. 79) suggest there were long lags between capital inflows and the real impact on the domestic economies of Canada and the USA but made no systematic cross-country comparison. If this were the case, we would expect the relationship between foreign capital inflows and output to appear in the medium to long run (e.g., after five to 15 years).

We also have the argument put forward by Fishlow that many countries simply mismanaged these inflows. This would suggest that the unconditional relationship between foreign capital and economic growth might be very slight. Two countries receiving equal amounts of capital could have very different outcomes depending on how such funds were spent.

Finally, and importantly, some countries suffered financial crises, which arguably arose directly due to their connection with foreign capital markets. These crises were likely to be associated with diminished economic growth bringing post-crisis incomes below where pre-crisis trends would have led the economy. ${ }^{11}$ It is also an open question as to whether income levels eventually returned to the levels suggested by the pre-crisis trend with growth rising above the pre-crisis trend until then or whether income levels would stay permanently depressed relative to trend with growth simply returning to the pre-crisis trend.

\footnotetext{
${ }^{11}$ Evidence from the IMF World Economic Outlook (2009) looks at the 'output gap' from zero to seven years after banking crises. The output gap is defined as the percentage point difference between where output would have been had growth followed the pre-crisis trend (i.e., the linear trend based on output movements from seven to three years before a crisis) and where output actually went. The average output gap since the 1970s has been seven percent for banking crises and 2.5 percent for currency crises. Similar values were noted prior to 1913 by Bordo, Eichengreen, Klingebiel and Martinez-Peria (2001) but using a slightly different metric.
} 


\subsection{Capital Flows and Financial Crises: An Indirect Association between Growth and Capital Flows}

Balance of payments problems, sudden stops, and crises are, and have been, part and parcel of international financial markets over the last 200 years. ${ }^{12}$ Figure 4 reports sample frequencies of crises (number of first years of crises divided by total number of country years without a crisis). Crises are rare, but the average country could expect some sort of crisis every 15 years or so. Crises are known to be costly events in terms of output losses (Bordo, Eichengreen, Klingebiel and Martínez-Peria, 2001), and they most likely reduce welfare due to market coordination failures and the absence of complete financial markets. ${ }^{13}$ Many factors cause financial crises, but it appears that one key ingredient is capital inflows.

Rancière, Tornell and Westermann (2008) build a model based on the idea that systemic financial crises (i.e., periods of inefficiently low investment and growth well below trend), are the side effect of receiving foreign capital flows. ${ }^{14}$ There are two key necessary conditions for the Rancière et. al. finding. First the economy benefits from a systemic bailout in the event of a crisis and, second, that contract enforcement problems exist but are neither too severe nor too mild. When this is so, agents take on foreign debt, use leverage to increase returns and investment and growth is higher than without foreign inflows. Along this equilibrium path however, a time-invariant probability of crisis and crash exists. ${ }^{15}$ Countries with high skewness of the growth of real credit in emerging

\footnotetext{
${ }^{12}$ Sudden stops are defined as large swings in the net inflow of foreign capital. They are often measured with positive changes in the current account or trade balance above a threshold level accounting for changes in reserve positions. The threshold is chosen so that the swings are abnormally large in a statistical sense at the country level.

${ }^{13}$ Allen and Gale (2000) analyze theoretically the possibility that banking and currency crises can be optimal. Crisis periods allow for optimal risk sharing. Marion (2000) argued that the assumptions of their model are unlikely to be fulfilled in practice. What one needs is that countries can issue large of amounts of debt in their own currency abroad and lend in equally large amounts to other countries in foreign currency. Since debt was largely contracted in foreign currency even in this period, it is unlikely that financial crises were optimal in the sense of Allen and Gale. More generally, crises could be beneficial in purging the system of inefficient over-investment as in older models of the business cycle.

${ }^{14}$ Two other sufficient conditions for systemic crises are that governments offer bailouts in systemic crises and that there are contract enforceability problems (i.e., borrowers cannot commit to re-pay their debt)..

${ }^{15}$ This is not due to a risk/return tradeoff. They assume the expected return on risky projects is lower than the safe project. Actors are also risk neutral. Volatility is higher when foreign borrowing occurs by assumption. Foreign borrowing can be welfare enhancing when crisis costs are not too large, crises are not too frequent and so forth. A shortcoming of this model is a lack of attention to risk aversion which could
} 
markets, i.e., with periods of financial crisis, grow faster in expectation. However, because of the time-invariant probability of crises there exist 'unlucky' paths where even such economies fail to grow faster than countries which take the safe path and do not borrow abroad.

Figure 5 illustrates three possible paths of output for hypothetical countries consistent with the model studied in Rancière et al. (2008) and similar to their Figure II. The risky paths represent two dynamic equilibria with capital inflows and the same ex ante probabilities of a financial crisis. They are distinguished from each ex post due to a different number of realizations of crisis events, and the lower 'unlucky' path is unable to attain higher long-run growth for this reason only. In the long run, or with a larger number of paths represented. the cross-sectional distribution of incomes would be representative of the long-run distribution of paths under capital inflows. The crosssectional mean growth rate and mean income levels would be higher than in the 'safe' no capital inflows equilibrium.

Figure 6 displays actual time-series paths of the logarithm of GDP per capita between 1880 and 1913. ${ }^{16}$ In Figure 6 we study two groups of countries: "high” capital importers had an average ratio of capital inflows to GDP above the median of the average within country capital flow ratio (taken over the period 1885-1913). ${ }^{17}$ In our sample this is a ratio above 0.63 percent of GDP. The countries in the "High" group are Argentina, Australia, Brazil, Canada, Chile, Mexico, New Zealand, Norway, Uruguay and the USA. The "Low" group consists of Austria, Denmark, France Germany, India, Italy, Japan, Portugal, Spain, and Sweden. A trend is also plotted in Figure 5 which is calculated as the average growth rate of the average level of the natural logarithm of GDP per capita within each group. There is no significant difference in the 34 year trend rates, they are 1.3 and 1.4 percent per year for the low and high groups respectively.

This similarity masks a long period of below trend growth for the "high" receivers in the 1890s and a period of above trend growth beginning roughly in 1900 and which coincides with the revival of international capital flows. The period between 1890 and

alter the costs and benefits of foreign capital flows substantial (Rancière et al, 2008 p.375 ftnt.11). Also crisis probabilities are exogenous to other crucial determinants of financial fragility that we explore below.

${ }^{16}$ Data on real GDP per capita are those underlying Obstfeld and Taylor (2003).

${ }^{17}$ The period is from 1885-1913 so as to include Argentina which has GDP data from 1885 only. Results are nearly identical without Argentina. 
1900 was marked by a major financial crisis for Argentina and several other recipients (Australia and the US amongst them) and also in London. This led to a major slowdown in global capital inflows. The first decade of the twentieth century witnessed a resurgence in capital flows.

Despite the apparent similarity in trend growth, there is evidence of slightly higher volatility in the "high" importing countries. Figure 7 presents a kernel density plot of average growth rates for the "high" and "low" group. This evidence suggests that the "high" capital importers faced somewhat more volatile growth rates without substantially altering their mean long-run growth rate of per capita GDP.

Figures 8a-8d provide further evidence on the relation between crises and income levels. Here we present plots similar to those in IMF (2009). Average income levels across countries are calculated in a window beginning six years before all the way to six years after banking, currency and debt crises as well as an indicator equal to one if any type of financial crisis occurred. We include here only the first year of any type of crisis. The dashed line represents the average growth rate for the countries in a window from six to three years before the crisis event. We stop the trend calculation three years prior to the crisis to avoid including abnormally high growth rates in the midst of economic booms. The trend is indexed relative to its value six years after the crisis and the deviation from this trend in index points is given by the solid line. The figures suggest medium term recovery from banking and currency crises but not from debt crises. In the short to medium-run (between 0 and three years) the income losses from these crises are quite visible. The data suggest a loss of one percent of income relative to the trend in the first, second and third years after a crisis for a cumulative loss of roughly three percent of income relative to trend. When we examine the 'all crisis' indicator which includes debt crises we see no return to pre-crisis trend levels even after six years.

Finally we present Figure 9 which displays a scatter plot of average growth rates of real GDP per capita between 1880 and 1913 versus the cumulative number of crisis events between these years. Each crisis event is the first year in any type of financial crisis so as to avoid counting, say, a currency and debt crisis that follow a banking crisis as three different events (although the plot is not much different to such a definition). 
Figure 9 shows that in the long-run there was no significant difference in growth rates between countries plagued by crises and those that avoided them all together.

The evidence from Figures 6 through 9 is not fully consistent with that from the recent period. Rancière et al. (2008) report that over ten year periods, between 1961 and 2000, countries in their sample with financial crises tend to grow on average faster. Although crises bring income down, the growth rates of these economies is strong enough preceding these events to make for higher average growth rates. They explain this in terms of a model of risk taking with moral hazard and default as described above. We find no evidence of this type of relationship in the nineteenth century. Growth rates are perhaps somewhat stronger coming out of crises relative to pre-crisis trends as Figures 8a-8d highlight, but not sufficiently high for long enough to make for higher trend growth. We discuss below whether this is because the countries of the late nineteenth century found an 'unlucky' path as illustrated in our Figure 5 and Figure II of Rancière et al. or whether the assumptions made in Rancière et al. are invalid for the late nineteenth century.

Still, findings more consistent with ours are available. Sebastian Edwards (2007) demonstrates that Latin American economic growth in the late twentieth century was significantly below trend due to sudden stops and current account reversals. ${ }^{18}$ Eichengreen and Leblang (2003) study the period 1880-1913 together with the subsequent 100 years. They conclude that capital controls are associated with higher growth, crises are associated with lower growth, and that capital controls limit the probability of a crisis which should lead to lower volatility. Rancière, Tornell and Westermann (2006) also investigate the impact of capital market liberalization (19802002) on annual growth in GDP per capita and an indirect channel going from liberalization to crises and back into (lower) growth. They find a direct positive effect of liberalization on growth in the short-run and a negative indirect effect on growth. Countries have higher growth rates (on the order of one percentage point faster) after

\footnotetext{
${ }^{18}$ Edwards does not study the direct impact of international capital market integration on growth.
} 
liberalization, but the average country that liberalized had its expected annual growth rate brought down by 0.15 percentage points due to increased exposure to crises. ${ }^{19}$

In the next section, we attempt to gauge the impact of capital market integration on income and the indirect, and possibly negative effects on income, via financial crises. We also aim to sort out the long-run versus the short-run relationships.

\section{Growth and International Capital Market Integration: The Empirical Evidence}

\section{$\underline{\text { 4.1 Pitfalls in Measurement }}$}

Multivariate econometric estimation of the impact of capital flows and crises is complicated by the fact that the time horizon over which one measures the outcomes of interest matters. Of course, estimating growth regressions in a cross-country panel raises many other econometric issues including endogeneity, heterogeneity and model selection in addition to data measurement problems. Yet, the pitfalls must be gauged against the ability to control more explicitly for unobservable heterogeneity, common factors across countries and other variables important for determining growth, In this spirit, we present some preliminary econometric evidence below that tries to disentangle the relationship between income and capital flows in the face of these obstacles to identification and specification.

Figures 4 and 5 illustrate one way in which the identification of the impact of capital flows in the data may be difficult. Assume that countries that receive more capital grow faster and take the country-year as the unit of analysis. In any given non-crisis year, the country more open to foreign financing will be growing more rapidly. In a crisis year, however, growth and output may be lower, but (by assumption here) crises are directly related to capital inflows. In a regression of growth of GDP per capita on capital flows and other controls, without controlling for crises, would tend to bias downwards the coefficient on capital inflows.

\footnotetext{
${ }^{19}$ Conditional on having a twin banking and currency crisis, the output loss is on the order of 10 percent of GDP. The value of 0.15 is the increased likelihood of having a crisis due to liberalization times the output loss of having a crises. This is roughly the expected loss from liberalization.
} 
Also by changing the unit of observation to five, ten or 30 year periods inferences can change dramatically. ${ }^{20}$ Assuming that crises are not too frequent, and are not too severe in terms of output losses, then over longer spans of time, say ten years, the crisisprone country may still have a higher growth rate. Such growth specifications are at risk of being incomplete since they would ignore the increased volatility and (again, by assumption) the lower income per capita relative to its pre-crisis trend. Also, the long-run measured growth rate can be brought down significantly via crises, and if crises occur sufficiently often, or are sufficiently severe, the measured growth rate of the large capital importer can decline to that below the non-receiving country. Finally, if there are diminishing marginal returns to capital, the identification of the positive growth impact of capital flows (assumed in this example) could be even harder to disentangle from the negative side effect of crises.

\subsection{Long and Short-Run Associations between GDP per capita, Capital Inflows and Crises}

\subsubsection{Model and Data}

Table 2 implements an autoregressive distributed lag model (ARDL $(p, q)$ ) for the logarithm of real GDP per capita with country fixed effects in error correction form otherwise known as a dynamic fixed effects model. The error correction representation allows us to explicitly study short-run and long-run relationships between capital flows, crises and output per capita. Our estimating equation is

$$
\Delta y_{i t}=\sum_{j=1}^{p-1} \psi_{j} \Delta y_{i t-j}+\sum_{j=0}^{q-1} \delta_{j} \Delta X_{i t-j}+\varphi\left[y_{i t-1}-\left(\beta X_{i t-1}\right)\right]+\varepsilon_{i t} .
$$

The dependent variable in equation (1) is the annual change (denoted by $\Delta$ ) in the logarithm of real GDP per capita (y). Short run associations between variables on the right hand side of equation (1) and GDP per capita are captured by using annual changes

\footnotetext{
${ }^{20}$ Schularick and Steger look at growth and income levels over five-year periods for the 1880-1913 and 1980-2002, Rancière, Tornell and Westermann (2008) study 10 year periods between 1961 and 200 and Prasad, Rajan and Subramanian (2007) look at the entire period 1970-2000.
} 
in the explanatory variables $(X)$. Further lags in these changes yield an indication of the medium run impact of such variables.

Long run relationships between GDP per capita are isolated in the error correction term in square brackets. Lagged levels of the explanatory variables and the dependent variable (i.e., the lagged level of the log of GDP per capita) are used here. The error term, $\varepsilon$, is a composite error term consisting of year dummies, country fixed effects and country-time idiosyncratic white noise errors. We report the product of long run coefficients $\beta$ and the speed of adjustment $\varphi$ below.

Our dynamic fixed effects model (1) assumes common transition dynamics across countries. Another approach is to allow for differences in the short-run coefficients across countries or both differences in the short-run and long-run coefficients. Those methods, the pooled mean group estimator and the mean group estimator along with the dynamic fixed effects model are discussed theoretically in Pesaran and Smith (1995). ${ }^{21}$ Our specification is comparable to that of Loayza and Rancière (2005) who investigated the short and long run impacts of financial development on growth. Another benefit of this method is that inclusion of sufficient lags of the variables of interest can mitigate endogeneity problems.

We include the contemporaneous change in capital inflows and up to four lags of this variable, the cumulative number of crises up to year $t$ and two lags of this variable. We also include one lag of the log difference of GDP per capita. For other variables we only include the contemporaneous annual changes to conserve on degrees of freedom. This particular lag structure allows us to get an indication of the possible horizons over which capital flows and crises can have an impact on output per capita as discussed above. Finally, since we have roughly 30 periods for each country, this estimation

\footnotetext{
${ }^{21}$ If there is a unique vector defining the long-run relationship between the variables and the lag orders are appropriately chosen and sufficiently long, then the error correction version of the auto-regressive distributed lag model provides consistent estimates of the parameters, regardless of whether the variables are stationary only after first differencing. The 'Nickell bias' arises when the lagged dependent variable and the error term are correlated due to the inclusion of country fixed effects. The bias diminishes as the length of the panel increases. In our case, since we have over thirty years of observations, the bias is likely to be minimal. The pooled mean group estimator and the mean group estimator allow for heterogeneous dynamics or different coefficients for each country on the short run changes. If heterogeneity exists then the dynamic fixed effect model is inconsistent.
} 
approach may be preferable to the system GMM models used by Schularick and Steger (forthcoming) which are suited for "large $N$ small $T$ " panels. ${ }^{22}$

We have chosen a lag structure based on minimization of the Akaike Information Criterion and the Bayesian Information Criterion. We allowed for up to four lags of the difference in capital inflows, up to three lags of the difference in cumulative crises. However, we limit the lag values on all other control variables at 0 so as not to ask too much of the relatively small data set. Both information criteria suggest a lag length of 0 for the ratio of capital inflows to GDP and inclusion of the first and lagged difference of the cumulative crisis variable.

Our sample covers the years 1880 to 1913 and includes a maximum of 20 countries: Argentina, Australia, Austria, Brazil, Canada, Chile, Denmark, France, Germany, India, Italy, Japan, New Zealand, Norway, Portugal, Spain, Sweden, United States, Uruguay. For a set of twelve countries we have savings data. ${ }^{23}$ This is a key control in standard empirical growth models, but it is unavailable for many countries. For comparison we also look at results omitting the savings variable from the same twelve plus eight other countries without such data between 1880 and $1913 .{ }^{24}$

Our data make a slightly unbalanced panel of countries using annual observations. The list of auxiliary explanatory variables includes the key robust determinants of growth according to Sala-i-Martin, Doppelhofer and Miller (2004). These also coincide with key variables used by Mankiw, Romer and Weil (1992) and later papers in the empirics of economic growth and capital flows. We include: the population growth rate, the percentage of the population enrolled in primary school, and the level of exports divided by GDP.

To capture the direct impact of global capital market integration we use the ratio of Stone's capital calls to GDP. Finally we control for the impact of crises by creating a

\footnotetext{
${ }^{22}$ See Roodman (2007) on this latter point.

${ }^{23}$ Where we do include savings, we do not adjust the savings variable downward for countries with capital outflows. Also the current account data is not directly comparable with the Stone data which would make a proper adjustment difficult. These savings data are from Taylor (2002) who calculated the ratio of savings to GDP as the current account surplus divided by GDP plus the ratio of investment to GDP. We also experimented with the investment ratio but found it to be insignificant..

${ }^{24}$ The set of twelve countries includes: Argentina, Australia, Canada, Denmark, France, Germany, Italy, Japan, Norway, Spain, Sweden, United States. The full sample of 20 countries includes: Argentina, Australia, Austria, Brazil, Canada, Chile, Denmark, Egypt, France, Germany, India, Italy, Japan, New Zealand, Norway, Portugal, Spain, Sweden, United States, Uruguay.
} 
variable measuring the cumulative number of crises a country has had. The crisis could be a currency, banking, twin (i.e., banking and currency) or debt crisis. A banking crisis in one year followed by a currency crisis in the next year would be counted as separate crisis events as would an ongoing banking, debt or currency crisis. For debt crises, we only code the first year of a debt crisis to avoid including the often long periods without negotiated settlement but in which the economy may have recovered.

We report tests for stationarity and cointegration in Table 1. Using the test for unit roots in panel data developed by Im, Pesaran and Shin (2003) we cannot reject that all variables in levels are non-stationarity except the growth rate of population. After first differencing (i.e., year-to-year differences) we reject the hypothesis that all variables are non-stationary except the school enrolment rate. In the lower panel of Table 1 we use the Im, Pesaran and Shin test on the residuals from country level regressions of the log of GDP per capita on the right hand side control variables to test for cointegration between income and these variables. We present tests that account for common time trends, a country-level intercept and with and without country level trends. These test statistics are given for the two main samples we work with. In all cases we find evidence of cointegration by rejecting the null hypothesis of stationarity of these residuals. ${ }^{25}$

\subsubsection{Baseline Results}

Table 2 shows our results for three baseline models. ${ }^{26}$ Column 1 presents results for the sample of twelve countries with savings data, column 2 presents results for the same countries without savings and column 3 reports results for the larger sample. First, rises in capital inflows generally have no statistically significant relationship in the shortrun with income per capita. Coefficients on changes in capital flows are significant in only the specification for 12 countries and when controlling for savings.. In both samples, there is a positive and significant relationship in the long run between income and capital

\footnotetext{
${ }^{25}$ Johansen trace statistics using one lag of all included variables and an intercept term for a trend in levels reject the null hypothesis of no cointegrating relationship between the variables in levels for all countries. Similarly, tests developed by Westerlund rejected no cointegration in a test suitable for panels.

${ }^{26}$ We correct standard errors for heteroscedasticity by using robust standard errors. We also cluster these at the country level to control for bias in the standard errors arising from arbitrary forms of serial correlation in the error term.
} 
inflows. This suggests capital flows during the nineteenth century had long gestation lags as discussed above, and it is consistent with the fact that the large infrastructure projects and railways that it often funded took many years to develop. The marginal long-run impact of capital inflows in column $1 \mathrm{~A}$ is $2.02(-1 *(0.376 /-0.186))$. A one standard deviation rise in the capital inflows to GDP ratio would be associated with a roughly seven percent rise in GDP in the 'long run'. The speed of adjustment parameter suggests that half of such a gain would be realized in three and a half years. In other words, a rise in inflows of this magnitude could have raised income per capita significantly. Moreover, it would have raised growth rates roughly one half of a percentage point above the average growth rate for 5 to 7 years. The long run impact in the larger sample is about half of the size in column 3 compared to that in column 1.

For both samples, crises bring income down in the year following a crisis. The coefficients are again larger in the smaller sample, but they imply income falls by between 1.5 percent to three percent in the short-run. This is equivalent to two years of growth for the average country. The long run coefficients reported on the right hand panel of Table 2 show that countries' income levels do not suffer in the long run by being crisis prone. Income per capita, conditional on observables and other covariates is not any lower for countries with a higher number of crises. This suggests that nations made up for crisis losses in income in the medium term as is also consistent with Figure 6.

The point estimates on the other coefficients support general results from crosscountry growth regressions although individually, many of the variables here are not statistically significant. There is some evidence consistent with conditional convergence based on the fact that lagged levels of GDP per capita are negatively associated with the annual growth rate. Overall, this specification suggests that crises bring incomes down in the short term but not in the longer-term, while capital flows are not associated with higher incomes in the short-run but are positively related to income in the long-run. ${ }^{27}$

\footnotetext{
${ }^{27}$ Results from the pooled mean group estimator suggest a positive relationship between income and capital inflows in the long run, but a negative relationship in the short run. Crises are associated with lower incomes in the short run, but the coefficients are insignificant. There may be quite a lot of heterogeneity in the data giving rise to the variance between these results and those in Table 2. We discuss this further below when we estimate crisis probabilities.
} 


\subsubsection{Alternative Specifications: The Uses of Foreign Capital}

Table 3 investigates whether the uses to which British capital were put led to differential associations with income. Infrastructure spending based on "development borrowing" was heralded by Fishlow as the key to benefiting from participation in global capital markets. Schularick and Steger (2008) show that investment rates are positively associated with Stone's capital inflows. A result which we also can confirm in an unreported regression.

We break Stone's capital call data down into three subcomponents: Capital directed to railways, capital directed to utilities and private entities (financial firms, raw materials firms and other industrial and miscellaneous private uses) and that directed to the government for other purposes. Stone's data give no further information on the use of government flows, but in some prominent cases, some of these funds might have gone to government sponsored infrastructure investment so some caution should be exercised in interpreting these results. Also there appears to be strong correlation between these flows when they are scaled by GDP. By including all three components collinearity may be clouding the results in Table 3.

In any case, Table 3 shows that there is no strong evidence of a short-run impact on income levels of inflows in any of these individual categories. The coefficient on the first difference of private inflows is positive and significant in the shorter sample. In both models of Table 3, financial crises are still associated with short-run downturns in income but have no long-run negative impact on income. The long-run coefficients on capital inflows show that larger inflows of railway capital were associated with lower income in the long run with the coefficient being significant in the shorter sample. However, countries that received higher private and government inflows had higher incomes in the long run. The negative sign on the level of railways investment is indicative of possible problems in collinearity among the regressors. Indeed the sign on the coefficient on railways is positive when we leave out other forms of investment flows.

\subsubsection{Endogeneity of Capital Flows}


An extensive literature on the output effects of financial crises exists arguing that it is difficult to sort out whether output shocks drive crises or crises drive output down. ${ }^{28}$ Use of longer lags of GDP in unreported specifications of the regressions above reassures us that endogeneity may not be a problem. This is all the more so given our extensive set of control variables. If so, our results present a relatively unbiased estimate of the impact of foreign capital flows on incomes. Moreover they support GMM results from Schularick and Steger (forthcoming) which control for endogeneity. We turn now to a closer analysis of the links between capital flows and crises. Still, we attempt an instrumental variables specification of our baseline model as a robustness check.

The size of capital flows to any given country from Britain had many determinants. If these flows were associated with unobservable characteristics of income and growth, then there is a potential for inconsistent estimates of the parameters on the inflows. An earlier literature that studied capital inflows for particular countries discussed push (British) and pull (receiving country) factors that determined the size of capital flows in any given year. Edelstein (1982) argued that British investors chose to invest in countries where prospects for growth (and high, risk adjusted payoffs) were large.. Key 'exogenous' push factors were British saving or wealth accumulation and the rate of return on domestic assets. Other studies of particular countries (Canada, the US and Argentina) suggest that British gross investment was a key exogenous driver of the amount of flows to particular markets.

These studies point to the possibility of using British variables as excluded instrumental variables to deal with the endogeneity of capital flows. Indeed we tried such a method in Table 4 using lagged British investment, its change, and the Bank of England discount rate as instruments. In the first stage, we found that the lagged level inflows were negatively correlated with British investment. These instruments were not particularly strong however, especially in prediction of changes in inflows. We found that the long-run coefficient on capital flows in column $1 \mathrm{~A}$ of Table 4 is smaller but not statistically significant than its statistically significant OLS estimate. A Hausmann test for

\footnotetext{
${ }^{28}$ Jalil (2010) argues that endogeneity is an issue for bank crises in American economic history. Still when bank crises can be traced to exogenous non-economic events they tend to depress output. See also Bordo et al. (2001) for a long run analysis.
} 
exogeneity suggests we cannot reject the exogeneity of capital inflows implying endogeneity is not a key concern.

\subsubsection{Types of Crisis}

In the recent literature (e.g, IMF 2009) banking crises have been cited as the most costly type of financial crisis in terms of output losses. Currency crises may be associated with sharp drop events but their costs may depend heavily on how much foreign debt is denominated in foreign currency, and how much of these liabilities exist (Bordo, Meissner and Stuckler, forthcoming). The impact could in other words be highly heterogeneous. Debt crises may be costly if countries rely on foreign capital inflows to keep investment high although releasing a country of the burden of debt may actually raise output in certain cases.

Table 5 breaks the crisis indicator out into these three different types of crisis to see if there are differential impacts on output. Consistent with Figures 8a-8d, it appears that banking crises and debt crises are driving the negative relationships in Table 2. Currency crises are not significantly related to income either in the short or the long run. Banking crises seem to have negative relationships with income in the short run but not the long-run. In the larger sample of column (2) in Table 5, the coefficient on the second lag of banking crises is only significant at the 83 percent level. In our smaller sample, the debt crises in Argentina and Spain decrease income by a statistically significant nine percent in the short run. It also appears that this type of shock is not overcome over the long run since the cumulative debt crisis indicator in levels is significant and negative. In the larger sample, which includes the two previous defaults and those of Portugal, Brazil and Uruguay, the long run relationship is negative and statistically significant effectively lowering income by 3.5 percent permanently. ${ }^{29}$

\section{$\underline{4.3 \text { Crises and Capital Flows }}$}

\footnotetext{
${ }^{29}$ We checked for endogeneity between crises and shocks to income by using 'treatment' regressions which allow for correlation between the unobservable factors driving crises and income shocks. We could not reject the hypothesis of no correlation between the error terms in the separate equations.
} 
As discussed above, exposure to foreign capital inflows is likely to heighten the probability of financial crises. This implies that capital inflows could indirectly raise income volatility and in the case of debt crises lower income permanently via a financial crisis channel. There are many possible connections between crises and capital flows. High inflows are often eventually associated with sudden stops of capital and sharp depreciations of the exchange rate. Such dislocations can cause problems if debt is denominated in foreign currency as it was for many countries and may in fact be a function of such fundamentals. ${ }^{30}$ Increased financial globalization can also be associated with a deterioration in monitoring and greater likelihood of crisis and contagion (cf. Calvo and Mendoza, 2000). The empirical links between capital flows and crises have been examined in depth elsewhere in our research and that of others. ${ }^{31}$ We briefly illustrate the relationship between capital flows and an indicator for all crises and separately the three forms of financial crisis (banking, currency and debt) in Table 6. We also test for whether some kinds of capital flows have a stronger relationship with crises than others. The probit models for crises use a parsimonious set of explanatory variables including capital inflows. These include the ratio of foreign currency debt to total (public) debt, whether a country was on the gold standard or not, the Bank of England discount rate and the lagged value of banking and currency crises. In column 6 of Table 6 we present an 'instrumental' variables probit model to allow for the possibility that unobservable or omitted factors which were driving the probability of crisis could also influence the level of capital inflows.

The results in Table 6 suggest that higher capital inflows were strongly related to a higher probability of having any kind of crisis. In column 5 we find that the marginal effects on railway inflows are statistically significant and positive but private or government inflows are not statistically significant. This is another possible explanation for the negative relationship between railway inflows and income found in Table 4. The result is consistent with several hypotheses such as maturity mismatch problems or moral hazard arising from interest guarantees which fell disproportionately onto such

\footnotetext{
${ }^{30}$ Evidence and arguments can be found in Catão (2007), Bordo, Cavallo, and Meissner (forthcoming), and Bordo and Meissner (2007). Ford (1962) examined the contractionary nature of depreciations associated with capital flow reversals in Argentina in the nineteenth century.

${ }^{31}$ Radelet and Sachs (1998) implicate capital flows with the East Asian financial crisis of 1997-98.
} 
investment. Revenues arising from railways were not immediate since neither construction nor development and settlement around the rail-lines were immediate, but interest payments had to be covered in the short term. Any relatively short-term financing for such projects could have been withdrawn or not renewed due to external shocks in the capital market. To the extent that short-term funding was present in other sectors, this might have been less of a problem. Governments could raise some tax revenue relatively quickly and firms could use cash reserves or increase export earnings to avoid default.

In terms of endogeneity, in column 6 the instrumental variables probit suggests an even stronger positive relationship between inflows and crises. ${ }^{32}$ Here a one standard deviation rise in inflows would raise the probability of a crisis by 0.52 . This is a very large impact considering the sample unconditional probability of having a crisis would have been 0.1 .

Overall, our finding is that capital inflows were an important determinant of financial crises. This implies that foreign capital was associated with higher volatility of income per capita via crises. Results from above showed that crises brought income below trend temporarily and debt crises, but not currency and banking crises, had a longrun negative impact on income per capita. This view is consistent with the idea that crises were short-run shocks to income and that in the medium term countries grew more quickly than trend to re-gain their losses.

\section{Discussion of the Direct and Indirect Impact of Capital Inflows}

Our comparative exercise suggests a positive association between income and foreign capital. This relationship worked over the medium term because of the nature of nineteenth century investment. To achieve the higher incomes made possible by capital inflows, growth accelerated typically by one half of a percentage point over five to seven years after a shock to capital inflows. In unreported error correction models for the growth rate, we found no relationship between the long-run growth rate and higher capital flows.

\footnotetext{
${ }^{32}$ The second lag of British investment and the second lag of the Bank of England discount rate are used as instruments for inflows.
} 
The model in Rancière et. al that capital flows raised growth through a leverage effect while exposing countries to more frequent crises finds some superficial support in the data. However, unlike Rancière et al., we are unable to replicate the finding that countries experiencing crises experienced significantly higher average growth rates in any decade prior to 1913.

One possibility is that borrowers took on less leverage which is the channel by which growth rises in Rancière et. al. Imperfect enforceability and systemic bailouts drive this result. In the nineteenth century, foreign loans often hypothecated revenues of railways or the customs houses leading to more severe consequences of default. Imperial relations and other interventions also could have helped enforce contracts (Mitchener and Weidenmier, forthcoming). On the other hand, investors may have viewed these actions as insurance which would have inefficiently increased supply. The record on bailouts is also mixed. Large banks were frequently supported by governments in the nineteenth century. In the midst of banking crises, governments gave implicit support to large banks (e.g., on New South Wales, Australia in 1893 see Hickson and Turner, 2002 and in Italy see Luzzato 1968). And yet only one bank survived the crisis of 1890 in Argentina (cf. Eichengreen ${ }^{* * *}$ ) and the banking system of Brazil crumbled in the Encilhamento (Triner and Wandschenider, 2005). Still, in Argentina in the 1880s, Eichengreen highlights how investments into railways were guaranteed by the Argentine government. In the US, where no institutional lender of last resort existed, banking crises occurred both due to panic and contagion among depositors but also for fundamental reasons (cf. Ó’Gráda and White, 2003, Moen and Tallman, 1992 and Jalil, 2010). The historical record is surely not as cut and dried as the assumptions in the theoretical model of Ranciere et al. Finally, another obvious possibility is that countries in the nineteenth century simply followed an 'unlucky' path like that in Figure 5. Even if all of the assumptions in Rancière et. al. held, the examination of the realization of the dynamic equilibrium is not sufficient to accept or reject such a theoretical model.

Beyond the assumptions of Rancière et. al., other recent historical work (Bordo, Cavallo, Meissner, forthcoming) looks into the domestic risk factors that strengthen the relationship between capital inflows, sudden stops and crises. Sudden stops accompanied by currency crashes and debt crises were more likely in the nineteenth century in 
countries with large foreign currency liabilities, low reserve positions and a low openness to trade. ${ }^{33}$ That research and the results presented here demonstrate clearly that capital inflows very likely had a partially negative impact on income via financial crises.

Nevertheless this negative impact does not seem to have been permanent. On average, countries that suffered the most from crises eventually regained their long-run trend. Some countries did better than this and others did worse. The basic fact is Canada for instance had 3 minor currency crises but was nearly always above the $90^{\text {th }}$ percentile in terms of capital inflows relative to GDP. Canada enjoyed strong economic growth on the back of railway investment and other infrastructure development. On the other hand, Argentina, with a severe debt crisis in 1890 and two other currency crises in 1885 and 1907 suffered from the long lasting impact of the 1890 debt crisis. Argentina's debt crisis led to a prolonged period of low growth and low capital inflows during the 1890s. Canada's capital flows fell somewhat too in the late 1890s but not nearly as much as in Argentina relative to their pre-crisis averages. The reasons for the differences between these two outcomes is hard to generalize. However we do know that Canada had the ability to maintain the gold standard peg, a stable banking system, the political ability to avoid excessive debt and to avoid debt default and the support and trust of capital markets.

Countries also increased the volatility of their incomes (not necessarily consumption) when they engaged with global financial markets. Whether consumption suffered a dramatic turn would depend on the extent to which risk sharing occurred. Net positions were likely somewhat more favourable than gross positions suggest so that agents could draw on foreign assets in times of need, The general population had other forms of covering wage and consumption risks including immigrant remittances to the old world and migration to more favourable environments due to the low restrictions on labor mobility. Still, the evidence on aggregate consumption smoothing and risk sharing remains a black hole. Two recent studies, Chabot and Kurz (forthcoming) and Jacks and Meissner (2007) are possibly the only studies on the issue. Chabot and Kurz show that British investors were well diversified in their investments suggesting that financial

\footnotetext{
${ }^{33}$ Although we found in Table 6 that hard currency debt was not associated with crises (consistent with Bordo and Meissner, 2006) Bordo, Meissner and Stuckler show that such debt does raise crisis probabilities when accompanied by a currency crash.
} 
volatility was minimized. Jacks and Meissner show that for Britain and the US risk sharing was surprisingly high, and that most consumption risks that could be covered with trade in financial assets were covered.

\section{The Net Benefits of Laissez Faire Financial Globalization: Some Tentative Conclusions}

We began by highlighting the basic features of the first era of globalization in capital markets. Cross border capital flows were often large. Asset trade was unencumbered by capital controls. British and European capital scoured the planet in search of high returns going to where natural resources were abundant and capital and labor were scarce. Capital combined with these factors of production to make for higher incomes.

Nations relying on capital inflows faced enhanced risk when making international capital market connections. Incomes fell substantially around the time of financial crises. Many countries paid the price of losing several years or more worth of economic growth in the face of multi-year crises. They appear to have rebounded in the long run; slightly higher volatility of output or total income resulted. Whether these contours imply welfare losses is a topic of further research.

Particular fundamentals exacerbated the likelihood capital flows and sudden stops would turn into financial crises with large income drops. In other work, we have outlined the role that foreign currency debt, currency mismatches, financial development and

other factors played in interacting with sudden stops of capital flows from the core countries (Cavallo, Bordo and Meissner, forthcoming).

Contrary to these results, some exceptional countries accumulated their domestic capital stock through the judicious application of foreign capital to productive investment and also avoided crises. They had already become relatively financially developed and had earned credibility in the eyes of international capital markets. Canada is one example but Australia and the Scandinavian countries are also in this group of countries.

Finally, foreign financing may also have conferred other benefits such as enhanced risk-sharing and consumption smoothing opportunities or improved policy. 
These dimensions of the benefits of integration are beyond the scope of our study but should be investigated since evidence from the last 30 years suggests the real benefits to integration are to be found here (IMF, 2007). Also, further investigation into how countries transition from being crisis prone to having credibility, along the lines of Hoffman, Postel-Vinay and Rosenthal (2007), will also be fruitful for understanding the long run evolution of the benefits and costs of participating in a financial system with global reach. 


\section{$\underline{\text { References }}$}

Allen, Franklin and Douglas Gale (2000) “Optimal Currency Crises” Carnegie Rochester Conference Series on Public Policy 53 (2000). Pp. 177-230.

Bekaert, Geert Campbell Harvey, and Christian Lundblad (2005) "Does Financial Liberalization Spur Growth?,” Journal of Financial Economics vol 77 (1) pp. 3-55.

Beim, David O. \& Calomiris, C.W. (2001) Emerging Financial Markets New York: MacGraw-Hill.

Bordo, Michael D. (2006) "Sudden Stops, Financial Crises, and Original Sin in Emerging Countries: Déjà vu?” NBER working paper 12393

Bordo, Michael D. Alberto Cavallo and Christopher M. Meissner (forthcoming) "Sudden Stops: Determinants and Output Effects in the First Era of Globalization, 1880-1913” Journal of Development Economics

Bordo, Michael D., Barry Eichengreen, Daniela Klingebiel. Maria-Soledad MartinezPeria, (2001). “Is the Crisis Problem Growing More Severe?” Economic Policy 32, pp. 51--75.

Bordo, Michael D. and Christopher M. Meissner (2007) “Financial Crises, 1880-1913: The Role of Foreign Currency Debt” in Sebastian Edwards, Gerardo Esquivel, and Graciela Márquez eds. The Decline of Latin American Economies: Growth, Institutions, and Crises pp. 139-194. Chicago: University of Chicago Press

Bordo, Michael D. and Christopher M. Meissner (2006) “The Role of Foreign Currency Debt in Financial Crises: 1880-1913 vs. 1972-1997” Journal of Banking and Finance 60 pp. 3299-3329.

Bordo, Michael D., Christopher M. Meissner and David Stuckler (forthcoming) "Foreign Currency Debt, Financial Crises and Economic Growth: A Long Run View” Journal of International Money and Finance.

Calvo, Guillermo and Enrique Mendoza (2000) "Rational contagion and the globalization of securities markets,” Journal of International Economics 51 (1) pp. 79-113

Catão, Luis A.V. (2007) "Sudden Stops and Currency Drops: A Historical Look” in Sebastian Edwards, Gerardo Esquivel, and Graciela Márquez eds. The Decline of Latin American Economies: Growth, Institutions, and Crises pp. 243-289. Chicago: University of Chicago Press

Chabot, Benjamin and Christopher J. Kurz (forthcoming) "That's Where the Money Was: Foreign Bias and English Investment Abroad, 1866-1907” Economic Journal. 
Clemens, Michael A. and Jeffrey G. Williamson (2004), "Wealth Bias in the First Global Capital Market Boom, 1870-1913," Economic Journal, 114 (April): 304-337

Collins, William J. and Jeffrey G. Williamson. (2001) "Capital-Goods Prices And Investment, 1879-1950," Journal of Economic History, v61(1,Mar), 59-94

Cottrell, P. L. (1975) British overseas investment in the nineteenth century. London: Macmillan.

Davis, Lance E. and Robert A. Huttenback Mammon and the pursuit of Empire: The political economy of British imperialism, 1860-1912.

Edelstein, Michael. (1982). Overseas Investment in the Age of High Imperialism. New York: Columbia University Press.

Edwards, Sebastian (2007) “Crises and Growth: A Latin American Perspective” NBER working paper 13019 .

Eichengreen, Barry (1995) "Financing Infrastructure in Developing Countries: Lessons From the Railway Age” The World Bank Research Observer vol. 10 (10), pp. 75- 91

Eichengreen, Barry (***) “The Baring Crisis in a Mexican Mirror” ***/

Eichengreen, Barry, Ricardo Hausmann and Ugo Panizza (2003) "Currency Mismatches, Debt Intolerance, and Original Sin: Why they are not the Same and Why it Matters.” NBER working paper 10036.

Eichengreen, Barry and David Leblang (2003) "Capital Account Liberalization And Growth: Was Mr. Mahathir Right?," International Journal of Finance and Economics, v8 (3, Jul), pp. 205-224.

Ferguson, N. and M. Schularick (2006). "The Empire Effect: The Determinants of Country Risk in the First Age of Globalization." Journal of Economic History vol. 66 (2) pp. 283-312.

Fishlow, Albert (1965). American Railroads and the Transformation of the Ante-bellum Economy. Cambridge, MA: Harvard University Press.

Fishlow, Albert (1986) "Lessons from the Past, Capital Markets and International Lending in the $19^{\text {th }}$ Century and the Interwar Years,” in Miles Kahler (ed.), The Politics of International Debt, Ithaca: Cornell University Press.

Flandreau, Marc and Zúmer (2004) The Making of Global Finance, 1880-1913, OECD: Paris. 
Foreman-Peck, James (1994) A History of the World Economy: International Economic Relations since 1850 London: Harvester, Barnes and Noble.

Gourinchas, Pierre Olivier and Olivier Jeanne (2006) “The Elusive Gains from

International Financial Integration” vol. 72 (3) Review of Economic Studies, pp. 715-741.

Hickson, Charles R. and Turner, John D (2002) "Free banking gone awry: the Australian banking crisis of 1893” Financial History Review vol. 9 pp. 147-167.

Henry, Peter Blair. (2007) "Capital Account Liberalization: Theory, Evidence, and Speculation”, Journal of Economic Literature 45(4), pp. 887-935.

Hoffman, Philip T., Gilles Postel-Vinay, and Jean-Laurent Rosenthal (2007) Surviving Large Losses: Financial Crises, the Middle Class, and the Development of Capital Markets. Cambridge, MA: Harvard University Press.

Im, Kyung So, M. Hashem Pesaran, Yongcheol Shin, (2003) "Testing for Unit Roots in Heterogeneous Panels.” Journal of Econometrics, 115, 53-74.

International Monetary Fund (2007) “Reaping the Benefits of Financial Globalization” report prepared by the Research Department at the International Monetary Fund.

International Monetary Fund (2009) World Economic Outlook. October, 2009

Washington DC. http://www.imf.org/external/pubs/ft/weo/2009/02/index.htm

Issawi, Charles. (1982) An Economic History of the Middle East and North Africa. Methuen and Co. Ltd: London.

Jalil, Andrew (2010) “A New History Of Banking Panics in The United States, 18251929: Construction And Implications” mimeo UC Berkeley Dept. of Economics.

Jones, Matthew T. and Maurice Obstfeld Saving, Investment, and Gold: A Reassessment of Historical Current Account Data available at http://www.nber.org/databases/jonesobstfeld/

Kose, M. Ayhan, Eswar Prasad, Kenneth Rogoff and Shang-Jin Wei (2006) "Financial Globalization: A Reappraisal” IMF working paper WP/06/189.

Loayza, Norman and Romain Ranciere (2005) “Financial Development, Financial Fragility and Growth” IMF working paper 05/170.

Luzzatto, G., 1968. L’economia italiana dal 1861 al 1894, Torino, Einaudi, 1991.

Mankiw, Greg, David Romer and David N. Weil (1992) "A Contribution to the Empirics of Economic Growth” Quarterly Journal of Economics vol. 107 (2) pp. 407- 437. 
Marion, Nancy P. (2000) “Optimal Currency Crises: A Comment” Carnegie Rochester Conference Series on Public Policy 53 (2000). pp. 231-238.

Mitchener, Kris and Marc Weidenmier (forthcoming) "Supersanctions and Sovereign Debt Repayment." Journal of International Money and Finance.

Moen, Joel and Tallman, Ellis W. (1992) "The Bank Panic of 1907: The Role of Trust Companies” The Journal of Economic History, Vol. 52, No. 3, pp. 611-630.

Obstfeld, Maurice, and Alan M. Taylor. 2003. "Sovereign Risk, Credibility and the Gold Standard: 1870-1913 versus 1925-31” The Economic Journal vol. 113 (487), pp. 241275.

Obstfeld, Maurice, and Alan M. Taylor. 2004. Global Capital Markets: Integration, Crisis, and Growth. Cambridge: Cambridge University Press.

Ó Gráda, Cormac and White, Eugene N. "The Panics of 1854 and 1857: A View from the Emigrant Industrial Savings Bank” The Journal of Economic History, Volume 63, Issue 01, March 2003, pp 213-240

Pesaran, M. Hashem and Ron P. Smith. "Estimating Long-Run Relationships from Dynamic Heterogeneous Panels.” Journal of Econometrics 68 (no. 1, 1995): 79-113.

Prasad, Eswar, Raghuram Rajan and Arvind Subramanian (2007) "Foreign Capital and Economic Growth” Brookings Papers on Economic Activity vol. 1 pp. 153.

Radelet, Steven and Jeffrey Sachs, (1998) "The East Asian Financial Crisis: Diagnosis, Remedies, Prospects,” Brookings Papers on Economic Activity 1, pp.1-74.

Rancière, Romain, Aaron Tornell and Frank Westermann (2006) "Decomposing the effects of financial liberalization: Crises vs. Growth" Journal of Banking and Finance vol 30 (12) pp. 3331-3348.

Rancière, Romain, Aaron Tornell and Frank Westermann (2008) "Systemic Crises and Growth” Quarterly Journal of Economics vol. 123(1) pp. 359-406.

Reinhart, C, Rogoff, K. Savastano, M., 2003. “Debt Intolerance”, Brookings Papers on Economic Activity 1, pp. 1--74.

Roodman, David, (2007) “How to Do xtabond2: An Introduction to 'Difference' and 'System' GMM in Stata” working paper 103 Center for Global Development.

Sala-i-Martin, X., Gernot Doppelhofer and R.I. Miller (2004). "Determinants of LongTerm Growth: A Bayesian Averaging of Classical Estimates (BACE) Approach” American Economic Review, 94 (4), pp. 813-835. 
Schularick, Moritz and Thomas M. Steger (2006) “Does Financial Integration Spur Economic Growth? New Evidence from the First Era of Financial Globalization” mimeo Free University of Berlin.

Stone, Irving (1999) The Global Export of Capital from Great Britain, 1865-1914. New York: St-Martin's Press.

Summerhill, William (forthcoming) Inglorious Revolution: Political Institutions, Sovereign Debt, and Financial Underdevelopment in Imperial Brazil. Yale University Press.

Svedberg, P. (1978) "The portfolio direct composition of private foreign investment in 1914 revisited.” Economics Journal, 88, pp.763-777.

Taylor, Alan M. (2002) “A Century of Current Account Dynamics” Journal of International Money and Finance vol 21 (6) pp. 725-748.

Triner, Gail and Wandschenider, Kirsten (2005) "The Baring crisis and the Brazilian Encilhamento, 1889-1891: an early example of contagion among emerging capital markets” Financial History Review vol 12(2) pp. 199-225.

Williamson, J (1964) American Growth and The Balance of Payments University of North Carolina Press: Chapel Hill. 


\section{Data Appendix}

Most of the data underlying this paper was used in previous work (Bordo and Meissner 2007 and Bordo and Meissner 2006) and is explained thoroughly in those sources. The bulk of the macro historical data set is that used in Bordo et. al. (2001). Controls in the growth regressions and incomes comes from data underlying Clemens and Williamson (2004) and Obstfeld and Taylor (2004) More expansive data descriptions and sources are listed in the working paper versions of our work on crises in NBER working papers 11173 and 11897.

\section{Crisis Dating:}

As in Bordo et. al ( 2001) we date currency and banking crises using both qualitative and quantitative evidence. For all countries besides Austria-Hungary, Russia, New Zealand, South Africa, Mexico, Turkey, Egypt, Uruguay and India we have relied on the dates of Bordo et. al. in both periods. For these countries personal correspondence with Sevket Pamuk (Turkey) Luis Bertola (Uruguay), and other published country sources were used to date remaining crises.

We have dated currency crises for remaining countries, when possible, by using an approach based on the exchange market pressure (EMP) methodology which looks at changes in reserves, the exchange rate and the interest rate using data available from Global Financial Data and data underlying Flandreau and Zúmer (2004) published on eh.net (http://eh.net/databases/finance/)

Debt crisis dates are based on Beim and Calomiris (2001). Only private lending to sovereign nations is considered when building those default dates. Not every instance of technical default is included in the chronology, the authors identified periods (six months or more) where all or part of interest/principal payments were suspended, reduced or rescheduled. Some of those episodes are outright debt repudiations, while others were reschedulings agreed upon mutually by lenders and borrowers. Additional data is taken from a spreadsheet underlying Reinhart, Rogoff and Savastano (2003). 


\section{Ratio of Foreign Currency Debt to Total Debt}

We collected data from various national sources on hard currency debt (cf. Bordo and Meissner, 2007) and augmented and compared this with data made available by Flandreau and Zúmer (2004). What we refer to as hard currency debt is public debt that carried a gold clause or was made payable at a fixed rate in a foreign currency. ${ }^{34}$

\footnotetext{
${ }^{34}$ The data appendices and the text in our previous work on crises has more to say about the structure of this debt.
} 
Figure 1 Average Levels of the Ratio of Capital Inflows to GDP for Different Types of Capital Importers, 1880-1913

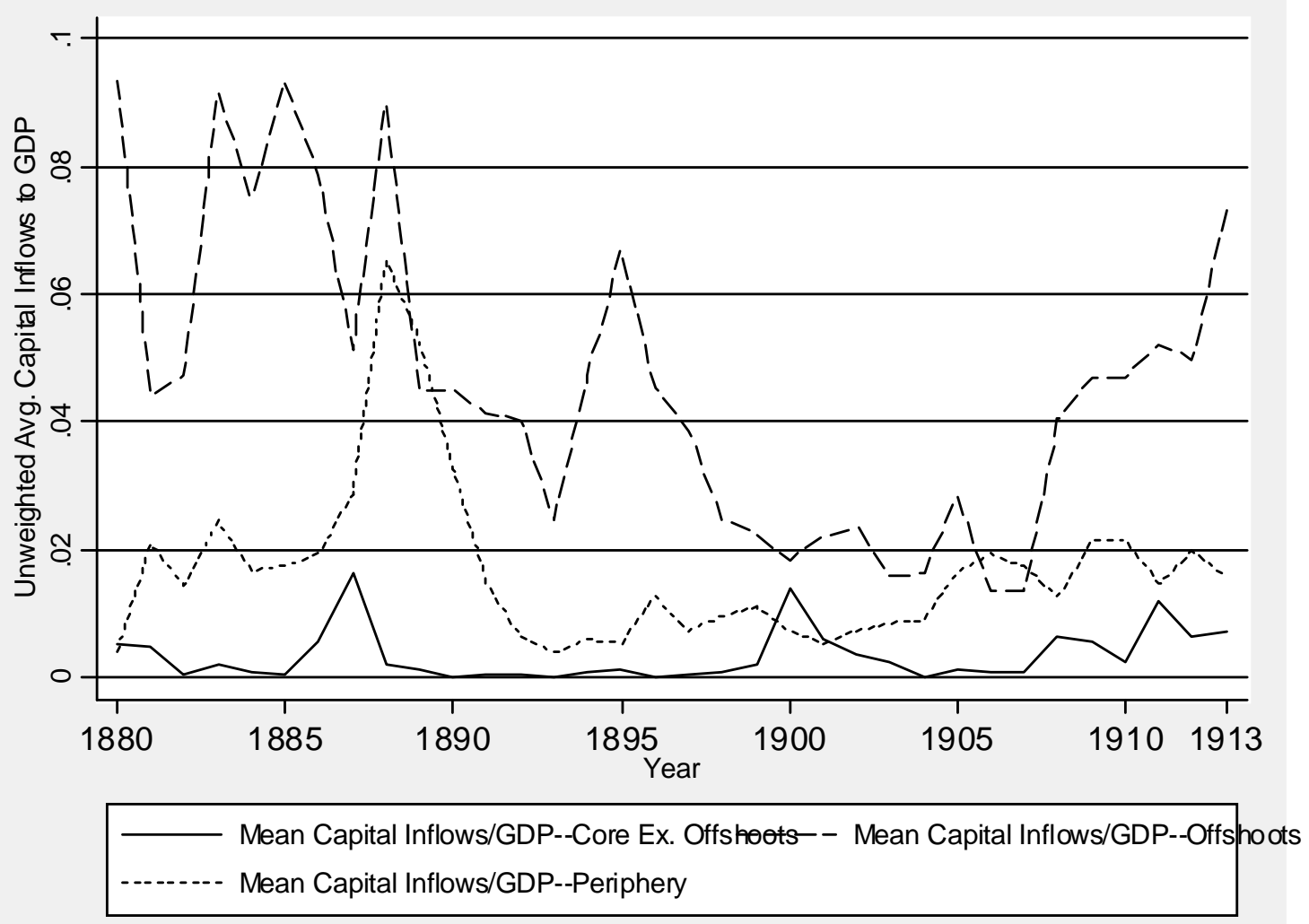

Notes: See text for countries in each category. Capital flows data are from Stone (1999) and GDP come from Clemens and Williamson (2004). 
Figure 2 The Average Share of British Capital for Three Categories of Investment, 1880-1913

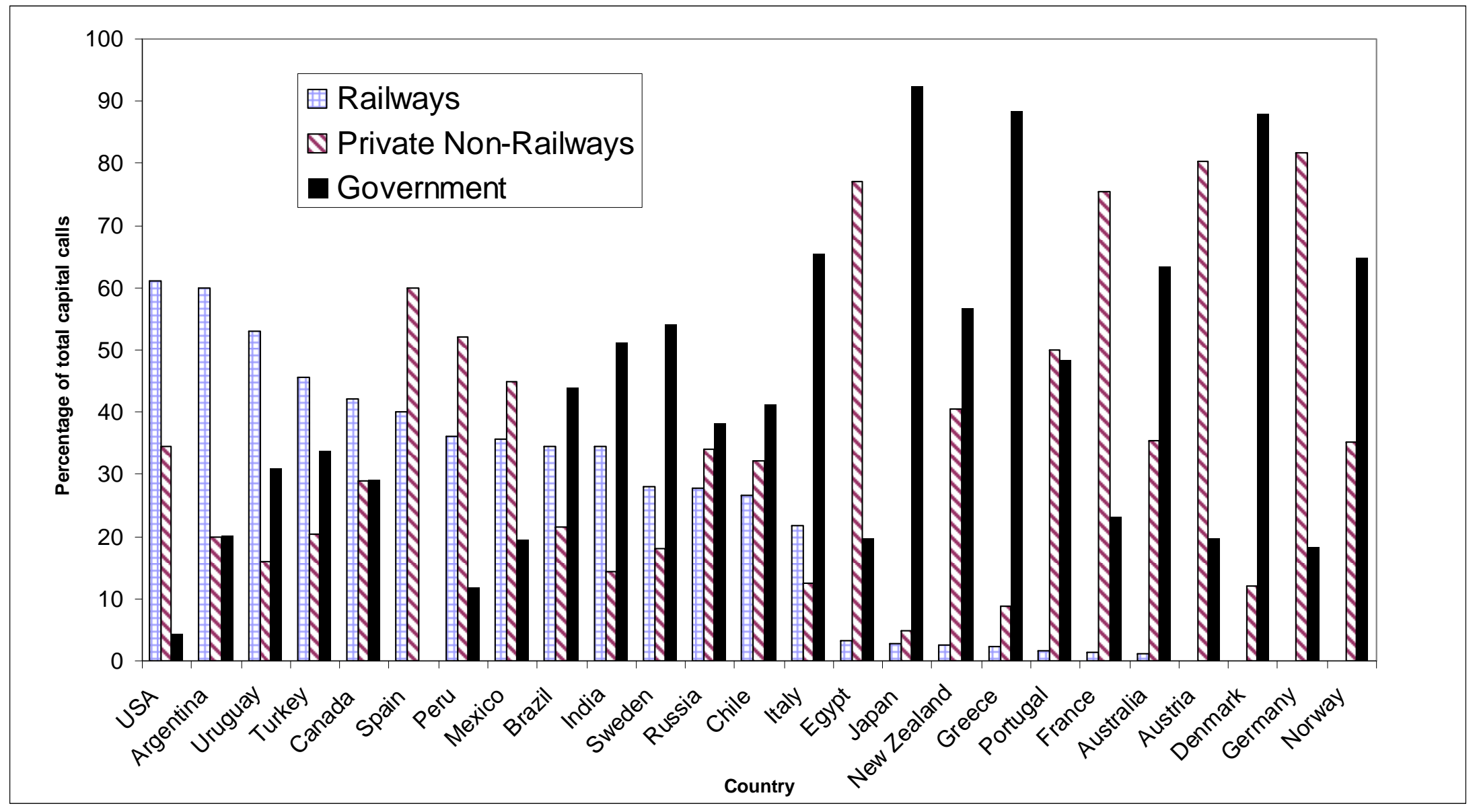


Figure 3 Bond Spreads versus a Measure of Productive Investment, 1874

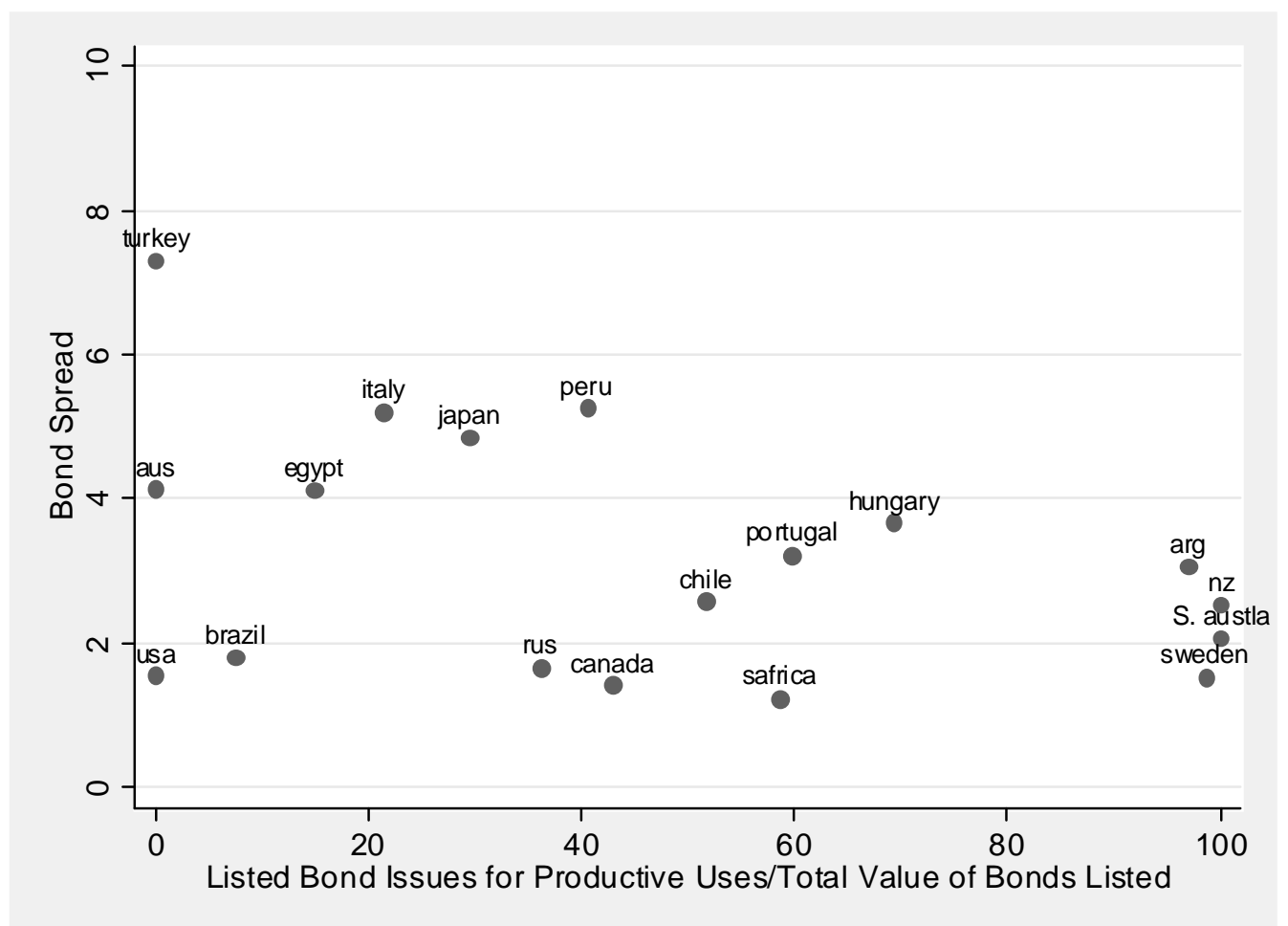


Figure 4 Crisis Incidence, 1880-1913

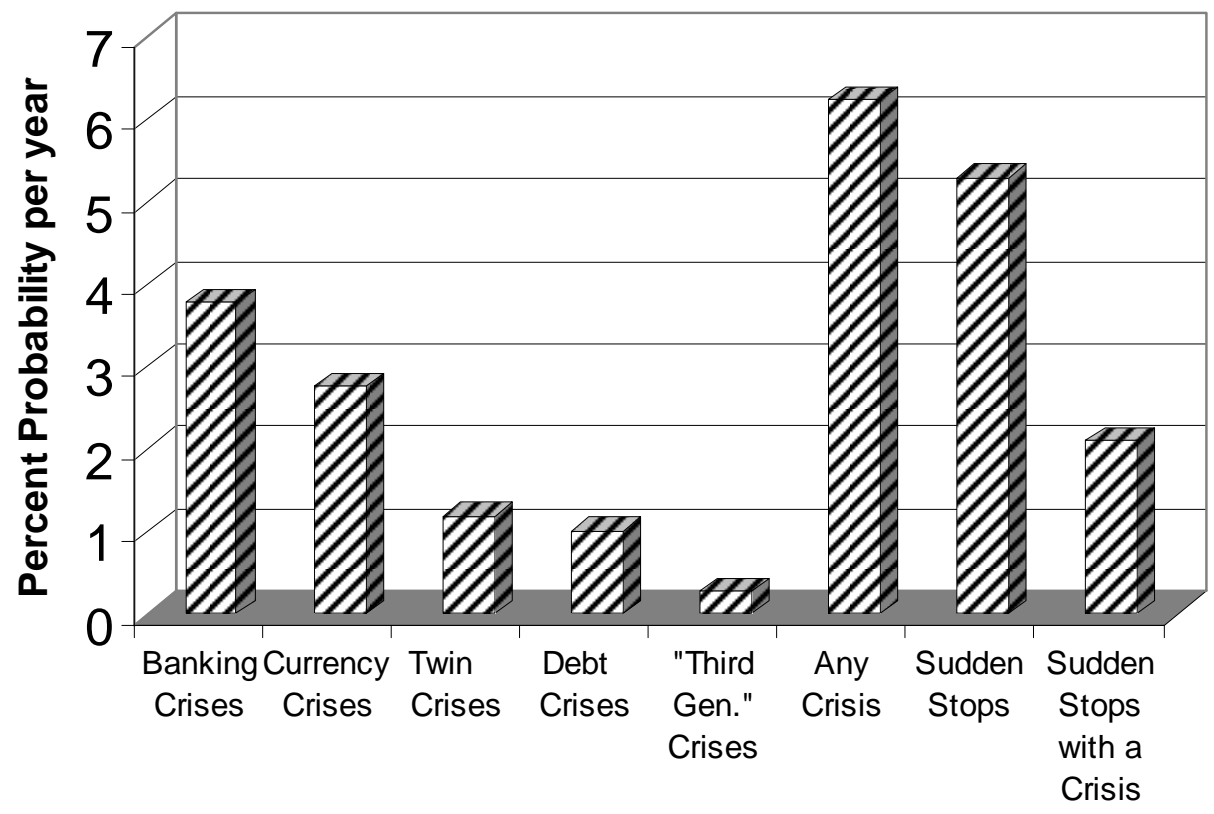

Type of Crisis

Notes: Crisis probability is the number of country years which witnessed the first year of a crisis divided by the number of country years without a crisis. Twin crises involve a banking and a currency crisis in the same year. Debt crises involve a sovereign default. Sudden stops are large swings in the current account or trade balance from deficit towards surplus. "Third generation” crises witnessed a banking, debt and currency crisis. 
Figure 5 Hypothetical Evolution of GDP per capita for Three Kinds of Countries.

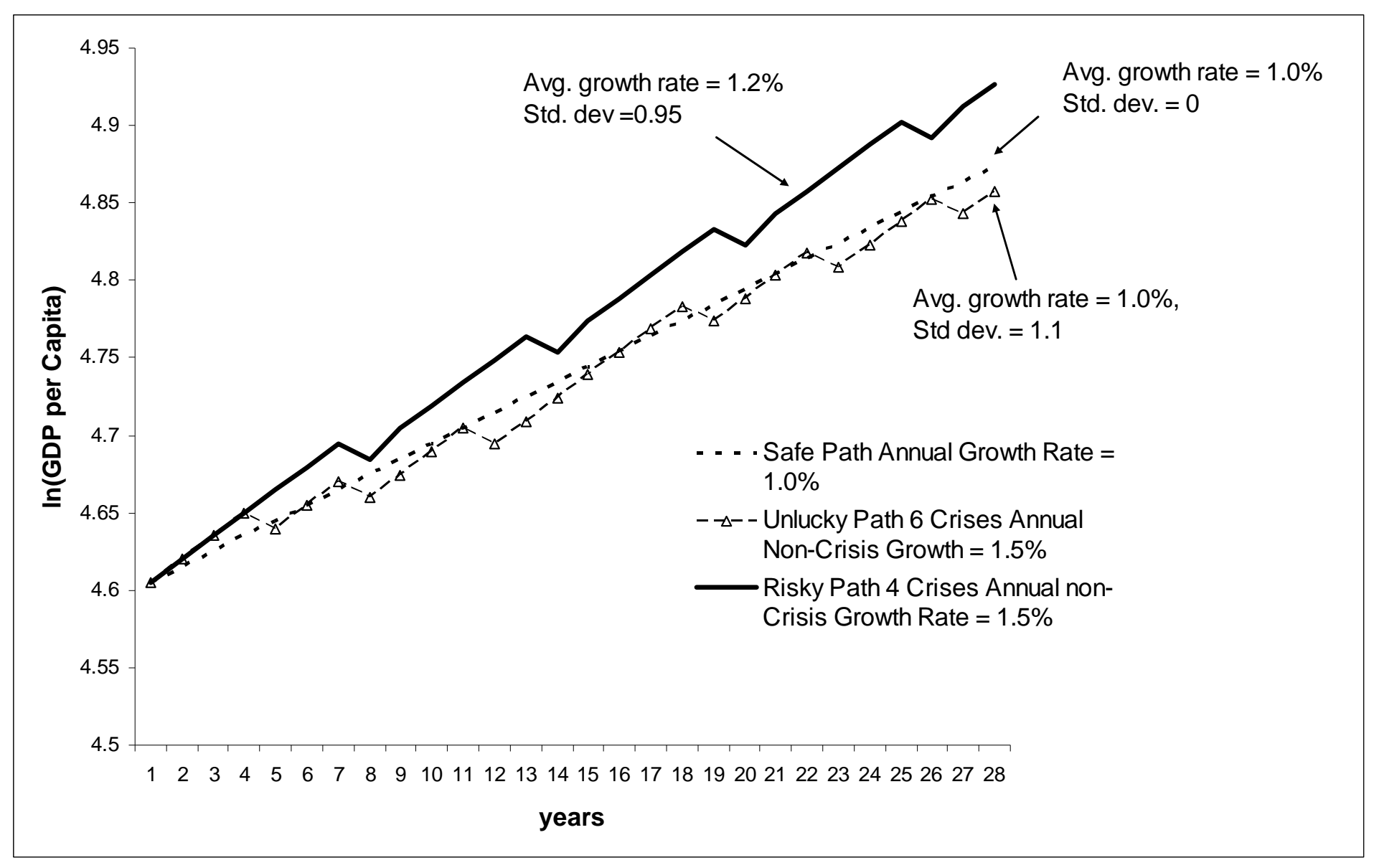

Notes: See text for assumptions underlying creation of these time series plots. 
Figure 6 Real GDP per capita and Capital Inflows to GDP, 1880-1913.

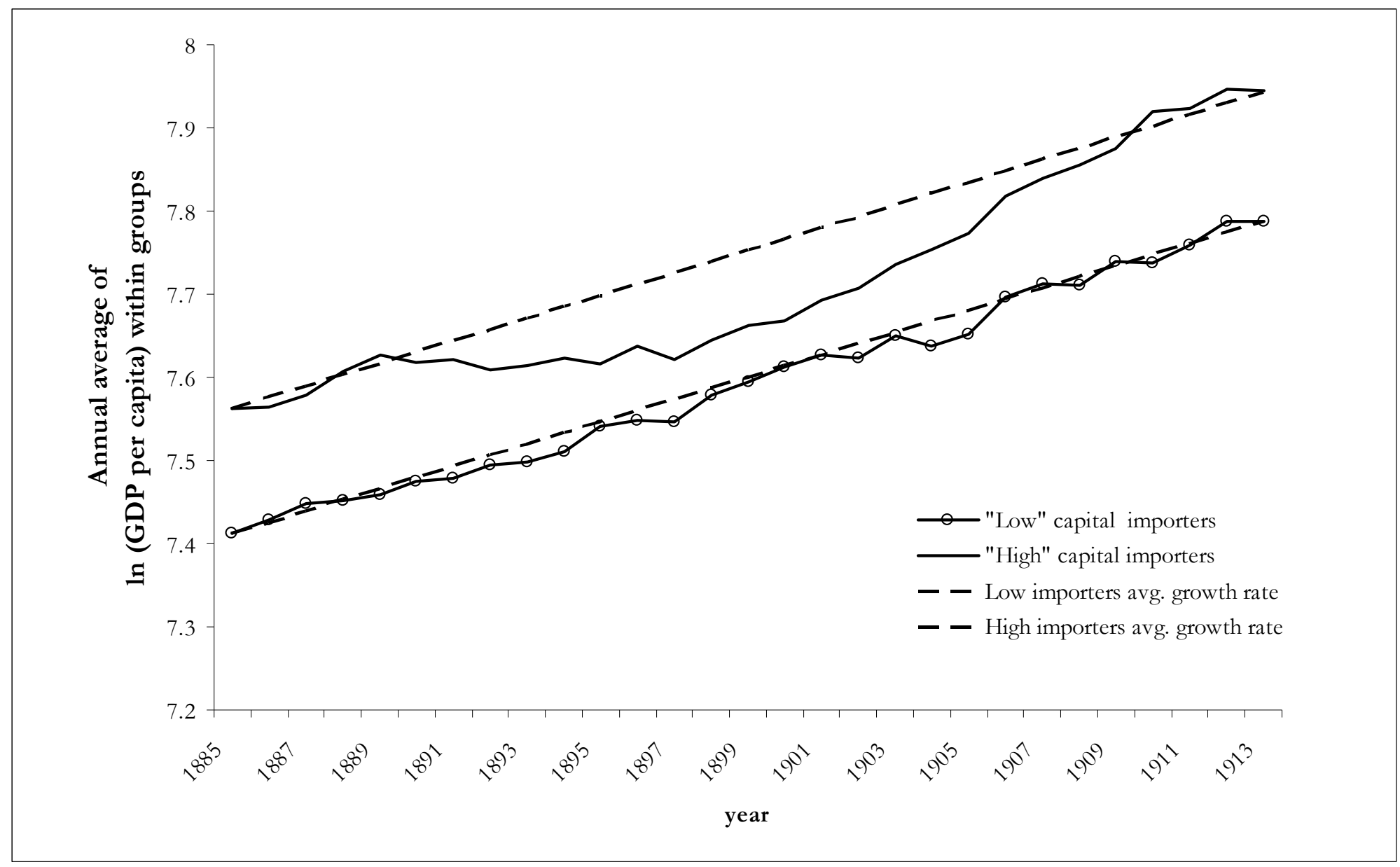

Notes: The countries in the "High" group are Argentina, Australia, Brazil, Canada, Chile, Mexico, New Zealand, Norway, and Uruguay. The "Low" group consists of Austria, Denmark, France Germany, India, Italy, Japan, Portugal, Spain, and Sweden and the USA. Average capital inflows for the "high" group are above 0.63 percent of GDP the median of the average ratio of inflows to GDP across countries. 
Figure 7 Kernel Density Plot of Growth of GDP per Capita for “High” and “Low” Capital Importers, 1885-1913

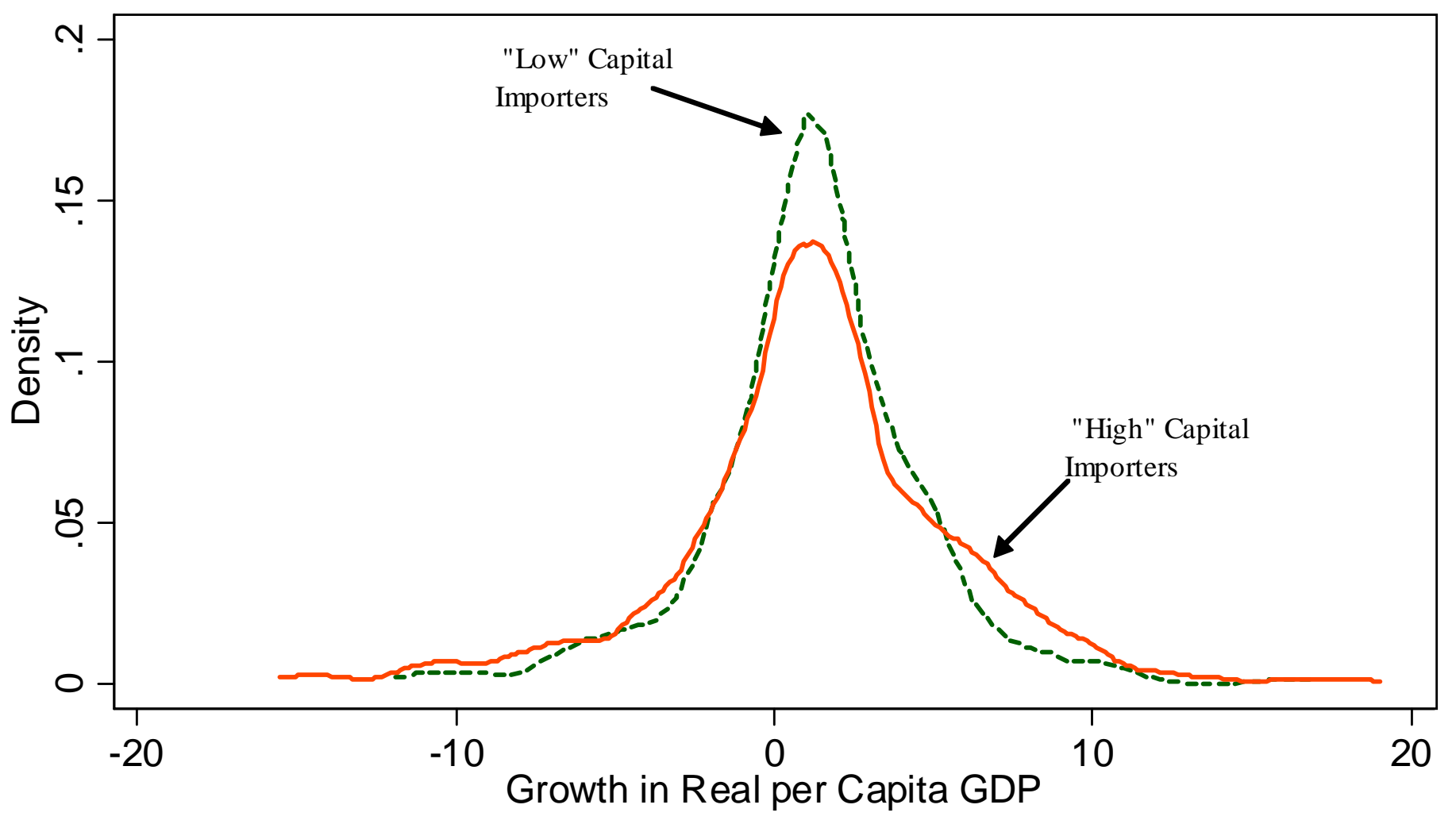


Figure 8a Output per Capita, trend Output per capita and Banking Crises

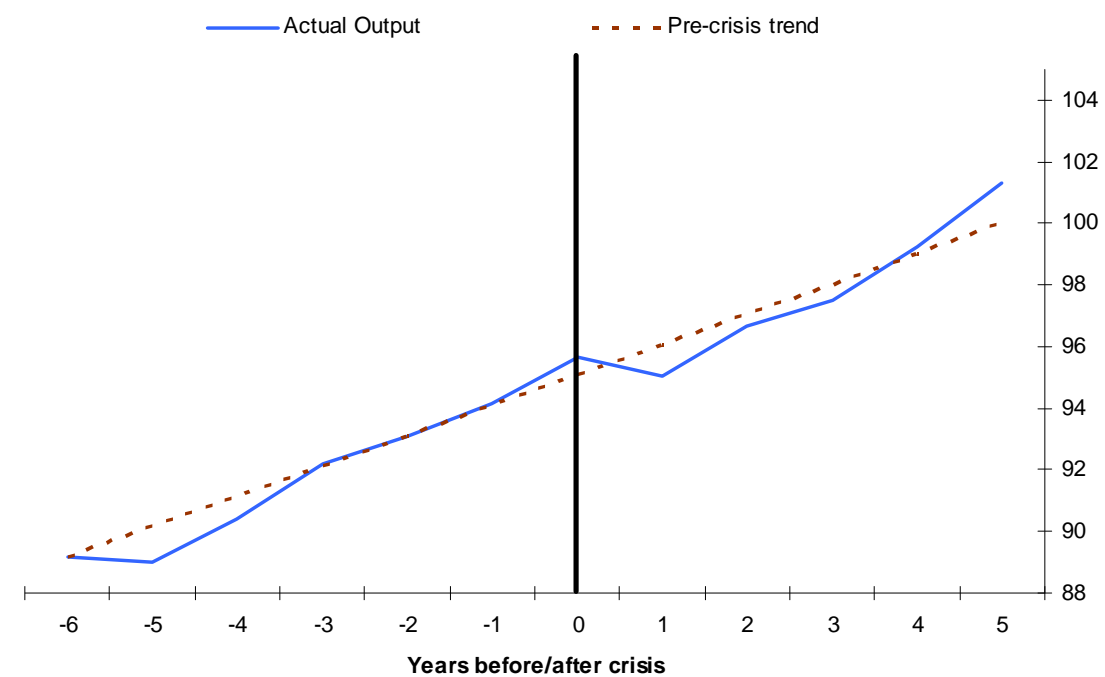

Figure 8b Output per Capita, trend Output per capita and Currency Crises

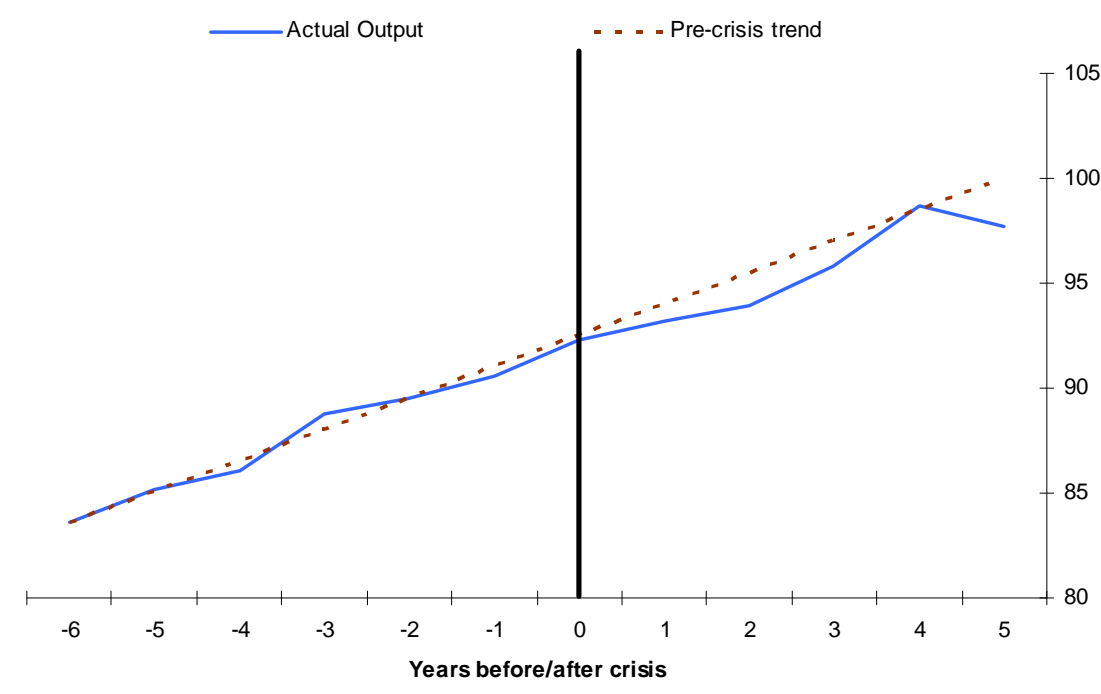

Figure 8c Output per Capita, trend Output per capita and Debt Crises

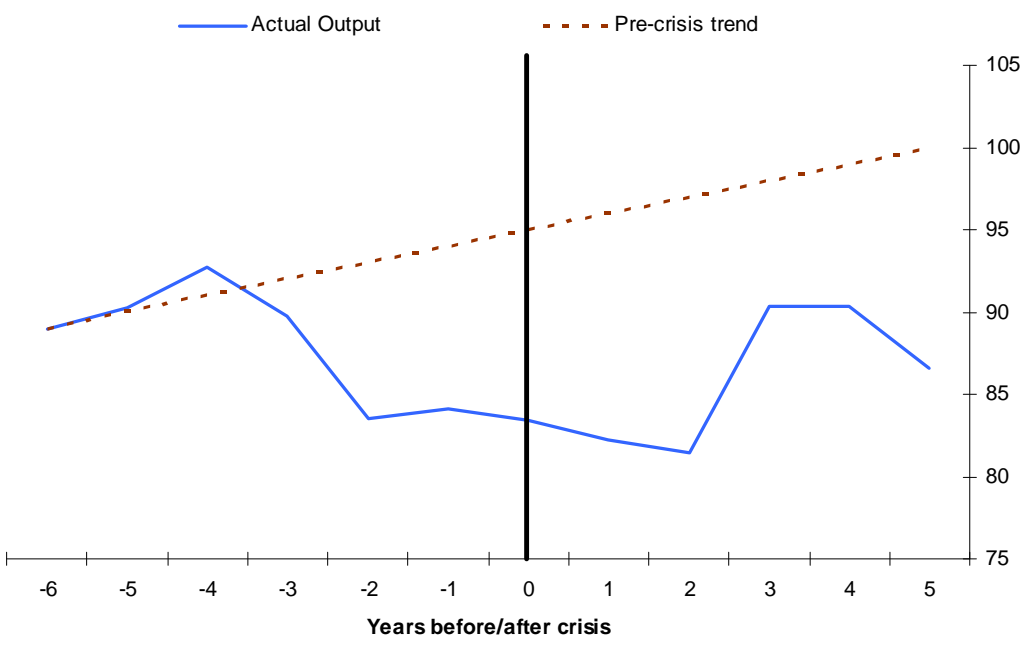

Figure 8d Output per Capita, trend Output per capita and any type of crisis

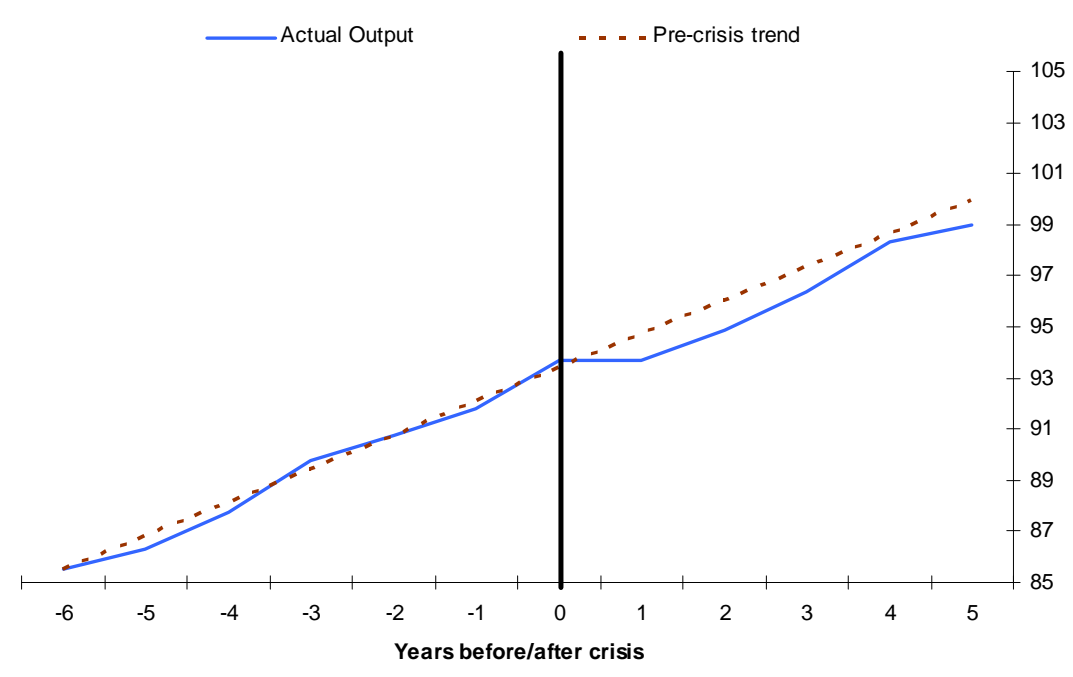


Figure 9 Average Growth of GDP per Capita, 1885-1913 and the Cumulative number of Crisis Events, 1885-1913

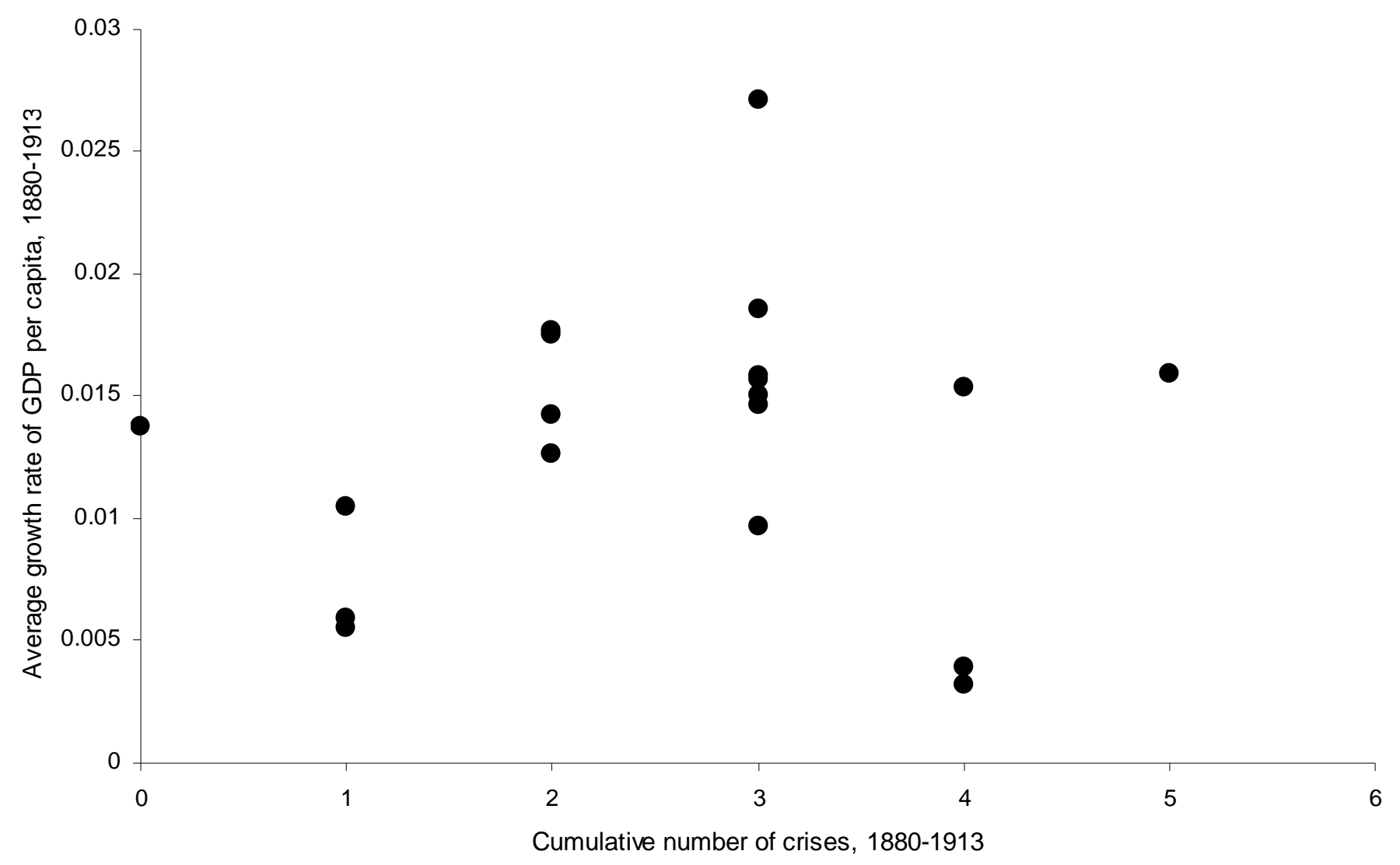


Table 1 Tests for Stationarity and Cointegration

\begin{tabular}{|c|c|c|c|c|c|c|}
\hline \multirow{2}{*}{$\begin{array}{c}\text { Pre-Tests for Stationarity of Regressors } \\
\text { Variables }\end{array}$} & \multicolumn{2}{|c|}{ Levels } & \multicolumn{2}{|c|}{ First Differences } & & \\
\hline & $\underline{W}[t-b a r]$ & $p$-value & $\underline{W}[t-b a r]$ & $p$-value & & \\
\hline In \{GDP per capita\} & 0.173 & 0.569 & -12.478 & $0.000 * \star \star$ & & \\
\hline Gross Capital Inflows/GDP & -1.400 & 0.081 & -12.285 & $0.000^{\star \star *}$ & & \\
\hline \multicolumn{7}{|l|}{$1880-1913$} \\
\hline Savings/GDP & -1.269 & 0.102 & -11.024 & $0.000^{\star \star \star}$ & & \\
\hline \multicolumn{7}{|l|}{ Enrolled in School } \\
\hline Exports/GDP & -0.718 & 0.237 & -16.057 & $0.000^{\star \star \star}$ & & \\
\hline Growth Rate of Population & -4.857 & $0.000^{\star \star \star}$ & -14.517 & $0.000^{\star \star *}$ & & \\
\hline $\begin{array}{c}\text { Panel, residual based tests for } \\
\text { cointegration }\end{array}$ & $\begin{array}{r}\text { withou } \\
\text { with S }\end{array}$ & $\begin{array}{l}\text { t trend, } \\
\text { avings }\end{array}$ & $\begin{array}{l}\text { with } t \\
\text { with } \mathrm{S}\end{array}$ & $\begin{array}{l}\text { trend, } \\
\text { avings }\end{array}$ & $\begin{array}{l}\text { without trend, } \\
\text { no savings }\end{array}$ & $\begin{array}{l}\text { with trend, } \\
\text { no savings }\end{array}$ \\
\hline $\begin{array}{l}\text { Im, Pesaran and Shin W[t-bar] statistic } \\
\mathrm{H}_{0} \text { : non-stationarity }\end{array}$ & -8.209 & $0.000 * \star \star$ & -7.511 & $0.000 * * *$ & $-9.6780 .000^{\star \star \star}$ & $-7.5110 .000^{\star \star \star}$ \\
\hline $\begin{array}{l}\text { Notes: The table present test-statistics for unit roc } \\
\text { for heterogeneous panels based on Im, Pesaran } \\
\text { Country level intercepts, country level time trends } \\
\text { unit root tests on the residuals from a regression } \\
\text { to GDP, population growth rates and savings rate } \\
\text { between GDP per capita and the other variables. }\end{array}$ & $\begin{array}{l}\text { levels an } \\
\text { (2003). T } \\
\text { ommon tin } \\
\text { oer capita } \\
\text { indicated }\end{array}$ & $\begin{array}{l}\text { d differenc } \\
\text { he series a } \\
\text { e trend ar } \\
\text { on capital } \\
\text {. A rejectic }\end{array}$ & $\begin{array}{l}\text { given vari } \\
\text { ationary u } \\
\text { where inc } \\
\text { nulative cr } \\
\text { null hypoth }\end{array}$ & $\begin{array}{l}\text { ables (as ir } \\
\text { Inder the n } \\
\text { dicated. Th } \\
\text { ises, enrol } \\
\text { hesis is cor }\end{array}$ & $\begin{array}{l}\text { thesis. } \\
\text { panel conducts } \\
\text { rates, savings rates } \\
\text { with cointegration }\end{array}$ & \\
\hline
\end{tabular}


Table 2 Income per Capita, Capital Market Integration and Financial Crises, 1880-1913

\begin{tabular}{|c|c|c|c|c|c|c|c|}
\hline Short Run Coefficients & (1) & (2) & (3) & Long Run--Coefficients on levels & $(1 A)$ & $(2 A)$ & $(3 A)$ \\
\hline Change in Gross Capital Inflows/GDP $t$ & $\begin{array}{c}0.277 \\
{[0.129]^{*}}\end{array}$ & $\begin{array}{c}0.187 \\
{[0.115]}\end{array}$ & $\begin{array}{c}0.193 \\
{[0.141]}\end{array}$ & Lagged Gross Capital Inflows/GDP & $\begin{array}{c}0.376 \\
{[0.105]^{\star * *}}\end{array}$ & $\begin{array}{c}0.272 \\
{[0.080]^{\star \star \star}}\end{array}$ & $\begin{array}{c}0.124 \\
{[0.058]^{\text {t* }}}\end{array}$ \\
\hline Change in Cumulative number of Crises, $1880-1913 t$ & $\begin{array}{l}-0.013 \\
{[0.009]}\end{array}$ & $\begin{array}{l}-0.013 \\
{[0.008]}\end{array}$ & $\begin{array}{l}-0.004 \\
{[0.005]}\end{array}$ & $\begin{array}{l}\text { Cumulative Number of Crises } \\
1880-1913\end{array}$ & $\begin{array}{c}0.004 \\
{[0.003]}\end{array}$ & $\begin{array}{c}0.003 \\
{[0.004]}\end{array}$ & $\begin{array}{c}0.001 \\
{[0.002]}\end{array}$ \\
\hline Change in Cumulative number of Crises, $1880-1913 t-1$ & $\begin{array}{c}-0.032 \\
{[0.012]^{\star *}}\end{array}$ & $\begin{array}{c}-0.03 \\
{[0.010]^{\star *}}\end{array}$ & $\begin{array}{c}-0.015 \\
{[0.008]^{*}}\end{array}$ & Lagged Savings/GDP & 0.15 & -.- & -.- \\
\hline Change in Savings/GDP & $\begin{array}{c}0.264 \\
{[0.153]}\end{array}$ & --- & --- & Lagged Percentage of the Population & $\begin{array}{c}{[0.060]^{* *}} \\
0.05\end{array}$ & 0.086 & 0.215 \\
\hline $\begin{array}{l}\text { Change in Percentage of the Population } \\
\text { Enrolled in School } t\end{array}$ & $\begin{array}{c}0.604 \\
{[1.458]}\end{array}$ & $\begin{array}{c}0.482 \\
{[1.401]}\end{array}$ & $\begin{array}{c}0.024 \\
{[1.577]}\end{array}$ & Enrolled in School & {$[0.295]$} & {$[0.379]$} & {$[0.210]$} \\
\hline Change in Exports/GDP $t$ & $\begin{array}{c}0.081 \\
{[0.292]}\end{array}$ & $\begin{array}{c}0.18 \\
{[0.252]}\end{array}$ & $\begin{array}{c}0.112 \\
{[0.069]}\end{array}$ & Lagged Exports/GDP & $\begin{array}{c}0.054 \\
{[0.224]}\end{array}$ & $\begin{array}{c}0.071 \\
{[0.250]}\end{array}$ & $\begin{array}{c}0.035 \\
{[0.037]}\end{array}$ \\
\hline Change in Growth rate of Population $t$ & $\begin{array}{c}0.817 \\
{[0.527]}\end{array}$ & $\begin{array}{c}0.886 \\
{[0.524]}\end{array}$ & $\begin{array}{l}-0.016 \\
{[0.352]}\end{array}$ & Lagged Growth Rate of Population & $\begin{array}{c}0.605 \\
{[0.549]}\end{array}$ & $\begin{array}{c}0.849 \\
{[0.534]}\end{array}$ & $\begin{array}{l}-0.188 \\
{[0.554]}\end{array}$ \\
\hline Change in In $\{$ GDP per capita\} $t-1$ & $\begin{array}{c}-0.214 \\
{[0.045]^{\star \star *}}\end{array}$ & $\begin{array}{c}-0.222 \\
{[0.054]^{\star \star *}}\end{array}$ & $\begin{array}{c}-0.174 \\
{[0.049]^{\star \star \star}}\end{array}$ & Lagged GDP per capita & $\begin{array}{c}-0.186 \\
{[0.057]^{\star \star *}}\end{array}$ & $\begin{array}{c}-0.169 \\
{[0.055]^{\star *}}\end{array}$ & $\begin{array}{c}-0.125 \\
{[0.041]^{\star \star *}}\end{array}$ \\
\hline Number of observations & 376 & 376 & 626 & & & & \\
\hline Number of Countries & 12 & 12 & 20 & & & & \\
\hline R-squared & 0.34 & 0.31 & 0.1 & & & & \\
\hline
\end{tabular}


Table 3 Income per Capita and the Use of Foreign Capital, 1880-1913

\begin{tabular}{|c|c|c|c|c|c|}
\hline Short Run Coefficients & (1) & $(2)$ & Long Run--Coefficients on levels & $(1 A)$ & $(2 A)$ \\
\hline Change in Railway Capital Inflows/GDP $t$ & $\begin{array}{c}0.11 \\
{[0.099]}\end{array}$ & $\begin{array}{l}-0.065 \\
{[0.315]}\end{array}$ & Lagged Railway Capital Inflows/GDP & $\begin{array}{c}-0.404 \\
{[0.169]^{\star *}}\end{array}$ & $\begin{array}{l}-0.224 \\
{[0.168]}\end{array}$ \\
\hline Change in Private non-Railway Capital Inflows/GDP $t$ & $\begin{array}{c}0.971 \\
{[0.366]^{\star *}}\end{array}$ & $\begin{array}{c}0.177 \\
{[0.357]}\end{array}$ & $\begin{array}{l}\text { Lagged Private non-Railway Capital } \\
\text { Inflows/GDP }\end{array}$ & $\begin{array}{c}0.574 \\
{[0.194]^{\star *}}\end{array}$ & $\begin{array}{c}0.12 \\
{[0.262]}\end{array}$ \\
\hline Change in Government Capital Inflows/GDP $t$ & $\begin{array}{c}0.066 \\
{[0.152]}\end{array}$ & $\begin{array}{c}0.311 \\
{[0.222]}\end{array}$ & $\begin{array}{l}\text { Lagged Government } \\
\text { Capital Inflows/GDP }\end{array}$ & $\begin{array}{c}0.618 \\
{[0.285]^{*}}\end{array}$ & $\begin{array}{c}0.336 \\
{[0.154]^{\star *}}\end{array}$ \\
\hline Change in Cumulative number of Crises, $1880-1913 t$ & $\begin{array}{l}-0.006 \\
{[0.009]}\end{array}$ & $\begin{array}{l}-0.001 \\
{[0.005]}\end{array}$ & $\begin{array}{l}\text { Cumulative Number of Crises } \\
\text { 1880-1913 }\end{array}$ & $\begin{array}{c}0.003 \\
{[0.003]}\end{array}$ & $\begin{array}{c}0 \\
{[0.002]}\end{array}$ \\
\hline Change in Cumulative number of Crises, $1880-1913 t-1$ & $\begin{array}{c}-0.022 \\
{[0.008]^{\star \star}}\end{array}$ & $\begin{array}{c}-0.014 \\
{[0.007]^{\star}}\end{array}$ & Lagged Savings/GDP & $\begin{array}{c}0.168 \\
{[0.078]^{\star}}\end{array}$ & --- \\
\hline Change in Savings/GDP & $\begin{array}{c}0.322 \\
{[0.113]^{\star \star}}\end{array}$ & --- & $\begin{array}{l}\text { Lagged Percentage of the Population } \\
\text { Enrolled in School }\end{array}$ & $\begin{array}{c}0.097 \\
{[0.291]}\end{array}$ & $\begin{array}{c}0.227 \\
{[0.212]}\end{array}$ \\
\hline $\begin{array}{l}\text { Change in Percentage of the Population } \\
\text { Enrolled in School } t\end{array}$ & $\begin{array}{c}2.244 \\
{[1.955]}\end{array}$ & $\begin{array}{c}0.261 \\
{[1.702]}\end{array}$ & Lagged Exports/GDP & 0.023 & 0.043 \\
\hline Change in Exports/GDP $t$ & $\begin{array}{l}-0.039 \\
{[0.241]}\end{array}$ & $\begin{array}{c}0.121 \\
{[0.073]}\end{array}$ & Lagged Growth Rate of Population & $\begin{array}{c}{[0.200]} \\
0.148\end{array}$ & $\begin{array}{l}{[0.036]} \\
-0.221\end{array}$ \\
\hline Change in Growth rate of Population $t$ & $\begin{array}{c}0.743 \\
{[0.567]}\end{array}$ & $\begin{array}{l}-0.028 \\
{[0.337]}\end{array}$ & Lagged GDP per capita & $\begin{array}{l}{[0.510]} \\
-0.152\end{array}$ & $\begin{array}{l}{[0.517]} \\
-0.122\end{array}$ \\
\hline Change In \{GDP per capita\} $t-1$ & $\begin{array}{c}-0.228 \\
{[0.045]^{\star \star \star}}\end{array}$ & $\begin{array}{c}-0.179 \\
{[0.045]^{\star \star \star}}\end{array}$ & & {$[0.056]^{\star *}$} & {$[0.040]^{\star \star *}$} \\
\hline $\begin{array}{l}\text { Number of observations } \\
\text { Number of Countries } \\
\text { R-squared }\end{array}$ & $\begin{array}{c}376 \\
12 \\
0.39\end{array}$ & $\begin{array}{l}626 \\
20 \\
0.2\end{array}$ & & & \\
\hline
\end{tabular}

Notes: Dependent variable is the annual change in log\{GDP per capita\}. Year dummies included but not reported. Hetreoscedasticity robust standard errors clustered

at the country level are in parentheses. See the text for precise definitions of variables.

${ }^{*}$ p-value $<0.1 ;{ }^{* *}$ p-value $<0.05 ;{ }^{* *} p$-value $<0.01$ 
Table 4 Endogeneity in the Relation between Output per Capita and Capital Market Integration, 1880-1913

\begin{tabular}{|c|c|c|c|c|c|c|c|}
\hline Short Run Coefficients & (1 OLS) & $(1 A / V)$ & (2 OLS) & $(2 A I V)$ & Long Run--Coefficients on levels & (1 OLS) & $(1 \mathrm{~A} / \mathrm{V})$ \\
\hline Change in Capital Inflows/GDP $t$ & $\begin{array}{c}0.289 \\
{[0.106]^{\star \star *}}\end{array}$ & $\begin{array}{l}-0.448 \\
{[1.005]}\end{array}$ & $\begin{array}{c}0.179 \\
{[0.068]^{\star \star *}}\end{array}$ & $\begin{array}{c}-0.274 \\
{[0.854]}\end{array}$ & Lagged Capital Inflows/GDP & $\begin{array}{c}0.331 \\
{[0.099]^{\star \star *}}\end{array}$ & $\begin{array}{c}0.162 \\
{[0.436]}\end{array}$ \\
\hline Change in Cumulative number of Crises, $1880-1913 t$ & $\begin{array}{c}-0.014 \\
{[0.007]^{\star *}}\end{array}$ & $\begin{array}{c}-0.021 \\
{[0.012]^{\star}}\end{array}$ & $\begin{array}{l}-0.003 \\
{[0.005]}\end{array}$ & $\begin{array}{r}-0.003 \\
{[0.006]}\end{array}$ & $\begin{array}{l}\text { Cumulative Number of Crises } \\
\text { 1880-1913 }\end{array}$ & $\begin{array}{c}0.005 \\
{[0.003]^{\star}}\end{array}$ & $\begin{array}{r}0.003 \\
{[0.006]}\end{array}$ \\
\hline Change in Cumulative number of Crises, $1880-1913 t-1$ & $\begin{array}{c}-0.034 \\
{[0.006]^{\star \star *}}\end{array}$ & $\begin{array}{c}-0.035 \\
{[0.008]^{\star \star *}}\end{array}$ & $\begin{array}{c}-0.017 \\
{[0.005]^{\star \star *}}\end{array}$ & $\begin{array}{c}-0.019 \\
{[0.008]^{\star *}}\end{array}$ & Lagged Savings/GDP & 0.158 & 0.1 \\
\hline Change in Savings/GDP & $\begin{array}{c}0.273 \\
{[0.072]^{\star \star *}}\end{array}$ & $\begin{array}{c}0.188 \\
{[0.140]}\end{array}$ & -- & -- & Lagged Percentage of the Population & $\begin{array}{c}{[0.069]^{\star *}} \\
0.221\end{array}$ & $\begin{array}{c}{[0.152]} \\
0.176\end{array}$ \\
\hline $\begin{array}{l}\text { Change in Percentage of the Population } \\
\text { Enrolled in School } t\end{array}$ & $\begin{array}{c}1.643 \\
{[1.511]}\end{array}$ & $\begin{array}{c}1.749 \\
{[1.716]}\end{array}$ & $\begin{array}{l}1.208 \\
{[1.127]}\end{array}$ & $\begin{array}{c}1.718 \\
{[1.403]}\end{array}$ & Enrolled in School & {$[0.209]$} & [0.295] \\
\hline Change in Exports/GDP $t$ & $\begin{array}{c}0.124 \\
{[0.136]}\end{array}$ & $\begin{array}{c}0.191 \\
{[0.172]}\end{array}$ & $\begin{array}{c}0.112 \\
{[0.059]^{*}}\end{array}$ & $\begin{array}{c}0.154 \\
{[0.101]}\end{array}$ & Lagged Exports/GDP & $\begin{array}{l}0.172 \\
{[0.105]}\end{array}$ & $\begin{array}{c}0.196 \\
{[0.122]}\end{array}$ \\
\hline Change in Growth rate of Population $t$ & $\begin{array}{c}0.393 \\
{[0.586]}\end{array}$ & $\begin{array}{c}0.732 \\
{[0.802]}\end{array}$ & $\begin{array}{l}-0.171 \\
{[0.299]}\end{array}$ & $\begin{array}{c}-0.08 \\
{[0.346]}\end{array}$ & Lagged Growth Rate of Population & $\begin{array}{l}-0.335 \\
{[0.577]}\end{array}$ & $\begin{array}{c}0.385 \\
{[1.144]}\end{array}$ \\
\hline Change In $\{$ GDP per capita $\} t-1$ & $\begin{array}{c}-0.05 \\
{[0.024]^{\star *}}\end{array}$ & $\begin{array}{l}-0.034 \\
{[0.050]}\end{array}$ & $\begin{array}{c}-0.045 \\
{[0.016]^{\star \star \star}}\end{array}$ & $\begin{array}{c}-0.038 \\
{[0.020]^{*}}\end{array}$ & Lagged GDP per capita & $\begin{array}{c}-0.05 \\
{[0.024]^{\star *}}\end{array}$ & $\begin{array}{c}-0.034 \\
{[0.050]}\end{array}$ \\
\hline $\begin{array}{l}\text { Number of observations } \\
\text { Number of Countries } \\
\text { R-Squared }\end{array}$ & $\begin{array}{c}376 \\
12 \\
0.22\end{array}$ & $\begin{array}{c}376 \\
12 \\
---\end{array}$ & $\begin{array}{c}626 \\
20 \\
0.12\end{array}$ & $\begin{array}{c}626 \\
20 \\
---\end{array}$ & & & \\
\hline
\end{tabular}

Notes: Dependent variable is annual growth rate of GDP per capita. Estimation in cols. $1 \mathrm{~A}$ and $2 \mathrm{~A}$ is by two stage least squares. Excluded instruments for capital flows are the lagged

level and change in Investment/GDP in the UK and Bank of England's discount rate. Hetreoscedasticity robust standard errors clustered at the country level are in parentheses.

See the text for precise definitions of variables. ${ }^{*} p$-value $<0.1 ;{ }^{* \star} p$-value $<0.05 ;{ }^{* \star \star} p$-value $<0.01$ 
Table 5 Output Effects by Type of Crisis, 1880-1913

\begin{tabular}{|c|c|c|c|c|c|}
\hline Short Run Coefficients & (1) & $(2)$ & Long Run--Coefficients on levels & $(1 A)$ & $(2 A)$ \\
\hline Change in Capital Inflows/GDP $t$ & $\begin{array}{c}0.036 \\
{[0.075]}\end{array}$ & $\begin{array}{c}0.14 \\
{[0.130]}\end{array}$ & Lagged Capital Inflows/GDP & $\begin{array}{c}0.177 \\
{[0.105]}\end{array}$ & $\begin{array}{c}0.064 \\
{[0.042]}\end{array}$ \\
\hline Change in Cumulative number of Currency Crises $t$ & $\begin{array}{c}0 \\
{[0.011]}\end{array}$ & $\begin{array}{c}0.001 \\
{[0.009]}\end{array}$ & Lagged Cumulative Currency Crises & $\begin{array}{c}0.008 \\
{[0.006]}\end{array}$ & $\begin{array}{c}0.005 \\
{[0.006]}\end{array}$ \\
\hline Change in Cumulative number of Currency Crises t- 1 & $\begin{array}{l}-0.019 \\
{[0.015]}\end{array}$ & $\begin{array}{c}-0.01 \\
{[0.010]}\end{array}$ & Lagged Cumulative Banking Crises & $\begin{array}{c}0.005 \\
{[0.007]}\end{array}$ & $\begin{array}{c}0.002 \\
{[0.005]}\end{array}$ \\
\hline Change in Cumulative number of Banking Crises $t$ & {$[0.013]$} & $\begin{array}{l}-0.005 \\
{[0.009]}\end{array}$ & Lagged Cumulative Debt Crises & $\begin{array}{c}-0.086 \\
{[0.017]^{\star * *}}\end{array}$ & $\begin{array}{c}-0.035 \\
{[0.010]^{\star * \star}}\end{array}$ \\
\hline Change in Cumulative number of Banking Crises t-1 & $\begin{array}{c}-0.033 \\
{[0.016]^{\star}}\end{array}$ & $\begin{array}{l}-0.015 \\
{[0.011]}\end{array}$ & Lagged Savings/GDP & $\begin{array}{c}0.194 \\
{[0.065]^{\star \star}}\end{array}$ & --- \\
\hline Change in Cumulative number of Debt Crises, 1880-1913t & $\begin{array}{c}-0.111 \\
{[0.024]^{\star \star *}}\end{array}$ & $\begin{array}{l}-0.026 \\
{[0.022]}\end{array}$ & $\begin{array}{l}\text { Lagged Percentage of the Population } \\
\text { Enrolled in School }\end{array}$ & $\begin{array}{c}0.004 \\
{[0.251]}\end{array}$ & $\begin{array}{c}0.165 \\
{[0.217]}\end{array}$ \\
\hline Change in Cumulative number of Debt Crises, 1880-1913 $t-1$ & $\begin{array}{c}-0.09 \\
{[0.067]}\end{array}$ & $\begin{array}{l}-0.026 \\
{[0.024]}\end{array}$ & Lagged Exports/GDP & 0.039 & 0.003 \\
\hline Change in Savings/GDP & $\begin{array}{c}0.365 \\
{[0.135]^{\star \star}}\end{array}$ & --- & Lagged Growth Rate of Population & $\begin{array}{c}{[0.207]} \\
0.718\end{array}$ & $\begin{array}{c}{[0.036]} \\
-0.061\end{array}$ \\
\hline $\begin{array}{l}\text { Change in Percentage of the Population } \\
\text { Enrolled in School } t\end{array}$ & $\begin{array}{c}0.421 \\
{[1.479]}\end{array}$ & $\begin{array}{l}-0.399 \\
{[1.382]}\end{array}$ & Lagged GDP per capita & $\begin{array}{c}{[0.626]} \\
-0.176\end{array}$ & $\begin{array}{l}{[0.575]} \\
-0.159\end{array}$ \\
\hline Change in Exports/GDP $t$ & $\begin{array}{c}0.024 \\
{[0.298]}\end{array}$ & $\begin{array}{c}0.091 \\
{[0.074]}\end{array}$ & & {$[0.047]^{\star * *}$} & {$[0.036]^{\star \star \star}$} \\
\hline Change in Growth rate of Population $t$ & $\begin{array}{c}0.868 \\
{[0.406]^{*}}\end{array}$ & $\begin{array}{c}0.025 \\
{[0.351]}\end{array}$ & & & \\
\hline Change In \{GDP per capita\} $t-1$ & $\begin{array}{c}-0.23 \\
{[0.042]^{\star \star *}}\end{array}$ & $\begin{array}{c}-0.166 \\
{[0.048]^{\star \star \star}}\end{array}$ & & & \\
\hline Number of observations & 376 & 626 & & & \\
\hline Number of Countries & 12 & 20 & & & \\
\hline R-squared & 0.37 & 0.2 & & & \\
\hline
\end{tabular}

Notes: Dependent variable is the annual change in log \{GDP per capita\}. Year dummies included but not reported. Hetreoscedasticity robust standard errors clustered

at the country level are in parentheses. See the text for precise definitions of variables. 
Table 6 The Determinants of Financial Crises, 1880-1913

\begin{tabular}{|c|c|c|c|c|c|c|}
\hline Regressors & $\begin{array}{c}\text { (1) } \\
\text { All Crises }\end{array}$ & $\begin{array}{c}\text { (2) } \\
\text { Currency Crises }\end{array}$ & $\begin{array}{c}\text { (3) } \\
\text { Banking Crises }\end{array}$ & $\begin{array}{c}\text { (4) } \\
\text { Debt Crisis }\end{array}$ & $\begin{array}{c}\text { (5) } \\
\text { All Crises--Type of Flow }\end{array}$ & $\begin{array}{c}\text { (6) } \\
\text { All Crises (Probit IV) }\end{array}$ \\
\hline Capital Inflows/GDP $t-1$ & $\begin{array}{c}0.004 \\
{[0.002]^{\star *}}\end{array}$ & $\begin{array}{c}0.003 \\
{[0.001]^{\star \star \star}}\end{array}$ & $\begin{array}{c}0.003 \\
{[0.001]^{\star *}}\end{array}$ & $\begin{array}{c}0.0003 \\
{[0.0002]^{\star * *}}\end{array}$ & --- & $\begin{array}{c}0.136 \\
{[0.068]^{\star *}}\end{array}$ \\
\hline Railway Capital Inflows/GDP $t-1$ & --- & --- & --- & --- & $\begin{array}{c}0.011 \\
{[0.003]^{\star * *}}\end{array}$ & --- \\
\hline $\begin{array}{l}\text { Private non-Railway } \\
\text { Capital Inflows/GDP t-1 }\end{array}$ & --- & --- & --- & --- & $\begin{array}{c}0.012 \\
{[0.007]}\end{array}$ & --- \\
\hline Government Capital Inflows/GDP $t-1$ & --- & --- & --- & --- & $\begin{array}{l}-0.006 \\
{[0.005]}\end{array}$ & --- \\
\hline Foreign Currency Debt/Total Debt & $\begin{array}{l}-0.002 \\
{[0.036]}\end{array}$ & $\begin{array}{l}-0.019 \\
{[0.019]}\end{array}$ & $\begin{array}{l}-0.001 \\
{[0.024]}\end{array}$ & $\begin{array}{c}0.002 \\
{[0.004]}\end{array}$ & $\begin{array}{l}-0.008 \\
{[0.037]}\end{array}$ & $\begin{array}{c}-0.5 \\
{[0.272]^{*}}\end{array}$ \\
\hline On the Gold Standard $t$ - 1 & $\begin{array}{l}-0.032 \\
{[0.054]}\end{array}$ & $\begin{array}{c}0.002 \\
{[0.016]}\end{array}$ & $\begin{array}{c}0 \\
{[0.028]}\end{array}$ & $\begin{array}{c}-0.005 \\
{[0.002]^{\star \star}}\end{array}$ & $\begin{array}{c}-0.03 \\
{[0.054]}\end{array}$ & $\begin{array}{l}-0.123 \\
{[0.269]}\end{array}$ \\
\hline Bank of England discount rate $t-1$ & $\begin{array}{c}0.028 \\
{[0.025]}\end{array}$ & $\begin{array}{c}0.022 \\
{[0.009]^{\star *}}\end{array}$ & $\begin{array}{c}0.022 \\
{[0.013]^{*}}\end{array}$ & $\begin{array}{c}0 \\
{[0.002]}\end{array}$ & $\begin{array}{c}0.024 \\
{[0.024]}\end{array}$ & $\begin{array}{c}0.149 \\
{[0.131]}\end{array}$ \\
\hline Banking Crisis $t$ - 1 & $\begin{array}{c}0.213 \\
{[0.138]^{\star *}}\end{array}$ & $\begin{array}{c}0.088 \\
{[0.075]}\end{array}$ & $\begin{array}{c}0.066 \\
{[0.084]}\end{array}$ & $\begin{array}{c}0.045 \\
{[0.041]}\end{array}$ & $\begin{array}{c}0.205 \\
{[0.141]^{\star *}}\end{array}$ & $\begin{array}{c}0.732 \\
{[0.429]^{*}}\end{array}$ \\
\hline Currency Crisis $t$ - 1 & $\begin{array}{c}0.141 \\
{[0.098]^{*}}\end{array}$ & --- & $\begin{array}{c}0.084 \\
{[0.064]}\end{array}$ & $\begin{array}{c}0.001 \\
{[0.006]}\end{array}$ & $\begin{array}{c}0.12 \\
{[0.100]}\end{array}$ & $\begin{array}{c}0.336 \\
{[0.344]}\end{array}$ \\
\hline $\begin{array}{l}\text { Number of obs } \\
\text { Pseudo-R-squared }\end{array}$ & $\begin{array}{l}541 \\
0.07\end{array}$ & $\begin{array}{l}541 \\
0.08\end{array}$ & $\begin{array}{l}541 \\
0.06\end{array}$ & $\begin{array}{l}541 \\
0.35\end{array}$ & $\begin{array}{l}541 \\
0.07\end{array}$ & 541 \\
\hline
\end{tabular}

Notes: Probit estimations are by maximum likelihood. Dependent variables are as listed at the top of each column. See text for further information.

Standard errors are clustered at the country level are in parentheses. See the text for precise definitions of variables.

${ }^{\star} \mathrm{p}$-value $<0.1 ;{ }^{\star \star} \mathrm{p}$-value $<0.05 ;{ }^{* \star \star} \mathrm{p}$-value $<0.01$ 